\title{
Dobra pomorzańskie Kierdejów (Kierdejowiczów) w ziemi lwowskiej w XV wieku
}

1. Pomorzany wraz $\mathrm{z}$ sąsiednimi wsiami w XV-XVIII wieku tworzyły klucz dóbr w historycznej ziemi lwowskiej'. Pod względem geograficznym ob-

${ }^{1}$ Literatura dotycząca Pomorzan jest dość obszerna, zwłaszcza w kontekście ich związku z Sobieskimi i królem Janem III oraz zabytków (zob. A. BIEDRzycKa: Bibliografia pomników kultury dawnych kresów poludniowo-wschodnich Rzeczypospolitej. Kraków 2000, s. $216-$ tu pełne zestawienie literatury). Wczesnym dziejom Pomorzan i ich okolicom wiele miejsca poświęcił jedynie B. ZAMORski: Kronika Pomorzańska wedtug źródeł miejscowych opowiedziana. Lwów 1867. Jest to jednak praca niemal w całości bałamutna. Wyjątkiem są niektóre odwołania do źródeł z archiwum dóbr Pomorzany (większość jednak błędna), gdyż autor przebywał długo w tym mieście i korzystał obficie z archiwaliów uporządkowanych przez Józefa Pruszyńskiego - właściciela Pomorzan i miłośnika pamiątek narodowych (Kraków, Archiwum Narodowe, Inwentarz zespolu (zbioru) akt Archiwum Dóbr Pomorzany z lat 1401-1900. Oprac. W. Bukowski. Kraków 1983 (mps), s. 7-8). Kilka zdań o Pomorzanach i Szpikłosach napisał I. SzARANIEWICZ (Rys wewnętrznych stosunków Galicyi Wschodniej w drugiej połowie XV wieku. Lwów 1969, s. 15, 22), nie unikając jednak genealogicznych pomyłek (uwzględnił Świnków jako posesorów tych dóbr, twierdząc jednocześnie, że trzymali je w tenucie z rąk Kierdejów). Na temat Pomorzan z dobrami pisał też w kontekście własności Kierdejów K. PUŁASKI: Ród Kierdejów podolskich, monografia historyczno-genealogiczna. W: TenżE: Szkice i poszukiwania historyczne. Seria 3. Kraków 1906, s. 177-180, 184. Na zachowane piętnastowieczne pieczęcie z herbem Kierdeja uwagę zwrócił natomiast M. HAIsIG: Herb Kierdeja w świetle zabytków sfragistyki średniowiecznej. Mies. Her. 1936, T. 15, nr 7-8, s. 121-122.

Źródła dotyczące Pomorzan i ich okolic znajdują się głównie w aktach grodzkich i ziemskich lwowskich wydanych w AGZ (T. 11-19), jak też pozostających w rękopisach w archiwum lwowskim (Центральний Державний Історичний Архів України у Львові, фонд: 9, опис 1 (Acta Castrensia Leopoliensia — dalej: CastrLeop); 10, опис 1 (Acta Terrestria Leopoliensia - 
szar ten jest częścią Wyżyny Podolskiej, która na północy ograniczona jest pasmem Gołogór rozciągających się od Lwowa łukiem na południowy wschód ku Bóbrce, a następnie na północny wschód w kierunku Złoczowa, gdzie przechodzi w pasmo Woroniaków, ciągnące się na północ i północny wschód oraz skręcające lekkim łukiem na wschód w okolicy Oleska. Stromymi północnymi zboczami tych wzgórz Wyżyna Podolska przechodzi w Wyżynę Wołyńską Ich południowe stoki są znacznie łagodniejsze i zmieniają się w płaskowyż podolski, poprzecinany ułożonymi południkowo płytkimi, zabagnionymi i nietworzącymi jarów dolinami rzek, które oddzielają od siebie wypukłe i pofałdowane grzbiety ${ }^{3}$. Tą krawędzią przebiega też główny dział wodny europejski, który oddziela zlewiska Morza Bałtyckiego i Morza Czarnego ${ }^{4}$. Rzeki, wypływając ze wspomnianych wzgórz, kierują się równolegle na południe, aż do Dniestru. W jednej z tych dolin nad Złotą Lipą leżą Pomorzany. Wododział między Złotą Lipą a Koropcem jest też granicą oddzielającą geograficzne Podole Zachodnie od Wschodniego ${ }^{5}$. Im bardziej na południe, tym głębszymi dolinami, przekształcającymi się w charakterystyczne dla Podola jary, płyną rzeki. Grzbiety zachodniej części wyżyny porastają lasy liściaste (bukowo-dębowe), które im dalej na wschód, tym stają się rzadsze, przypominając krajobraz parkowy, i coraz częściej są poprzegradzane roślinnością stepową, którą później zastąpiły pola uprawne. Między Strypą a Seretem

dalej: TerrLeop); 14, опис 1 (Acta Terrestria Premisliensia — dalej: TerrPrem)) oraz w licznych zespołach AGAD: Metryce Koronnej, kopiariuszu dokumentów z tzw. rewizji listów w 1563 r. (tzw. Metryka Litewska, sygn. IV. B. 9), dokumentach pergaminowych (AGAD, Zbiór Dokumentów Pergaminowych — dalej: AGAD, perg.) oraz w Zbiorze Czołowskiego (sygn. 6). Ważnym uzupełnieniem są zachowane fragmenty archiwum pomorzańskiego (Archiwum Narodowe w Krakowie, Archiwum Dóbr Pomorzany — dalej: ADPom.), które po śmierci Józefa Pruszyńskiego w 1879 r. uległo rozproszeniu i częściowemu zniszczeniu. Jego resztki trafiły do Łańcuta do archiwum Potockich, którzy stali się nowymi właścicielami Pomorzan, a następnie w 1949 r. wraz z archiwum łańcuckim do Krakowa (Stownik geograficzny Królestwa Polskiego i innych krajów stowiańskich. Red. F. Sulimierski, B. Chlebowski, W. Walewski. T. 1-15. Warszawa 1880-1914 (dalej: SG) — tu: T. 8, s. 753; E. ChwALEwIK: Zbiory polskie. Archiwa, biblioteki, gabinety, galerje, muzea i inne zbiory pamiatek przeszłości w ojczyźnie i na obczyźnie. T. 2. Warszawa-Kraków 1927, s. 75-76; Kraków, Archiwum Narodowe, Inwentarz zespotu..., s. 7-8).

2 K.J. Hladylowicz: Zmiany krajobrazu w ziemi lwowskiej od połowy XV do początku XX wieku. W: Studia z historii społecznej i gospodarczej poświęcone Profesorowi dr Franciszkowi Bujakowi. Lwów 1931, s. 101-102; S. SRoKowski: Zarys geografii fizycznej ziem polsko-litewsko-ruskich. Kijów 1918, s. 55. Płyta podolska pochyla się w całości w kierunku SE, a najwyższe wzniesienie osiąga właśnie na krańcu NW (J. SMoleŃski: O powstaniu pótnocnej krawędzi podolskiej i o roli morfologicznej młodszych ruchów Podola. Kraków 1910, s. 3).

${ }^{3}$ K.J. Headylowicz: Zmiany krajobrazu..., s. 103; S. SRokowski: Zarys geografii fizycz$n e j . . .$, s. $62-63$.

${ }^{4}$ J. SMOLEŃSKI: O powstaniu pótnocnej krawędzi..., s. 4.

${ }^{5}$ K.J. HєAdyŁowicz: Zmiany krajobrazu..., s. 103; S. SRokowski: Zarys geografii fizycz$n e j . .$, s. $62-63$. 
pojawiają się już większe, charakterystyczne dla Wschodniego Podola stepy (Pantalicha) ${ }^{6}$.

2. Rodzina Kierdejowiczów, wywodząca się z Wołynia, pojawiła się na Podolu i Rusi Czerwonej na przełomie XIV i XV wieku? . Jej pierwszym działającym na tym obszarze przedstawicielem był Hryćko Kierdejowicz ${ }^{8}$. Pojawił się on na Rusi Czerwonej jeszcze za rządów Władysława Opolczyka. W 1376 roku świadkował na dokumencie księcia dla Maliana Szhamowicza z nadaniem Pieczychwostów, w 1388 roku zaś wystąpił w aktach miejskich lwowskich ${ }^{9}$. Wczesne związki Hryćka z Rusią Halicką potwierdza dokument Klemensa z Moskorzowa, starosty sanockiego i podkanclerzego Królestwa, z 5 maja 1400 roku (jeszcze sprzed objęcia przez Hryćka funkcji starosty kamienieckiego), wystawiony w Sanoku i odgraniczający lasy królewskie Bieszczady od dóbr Jaczka Rusina, sędziego sanockiego, na którym to akcie Hryćko także świadkował ${ }^{10}$.

3. Objąwszy rządy na Podolu z rąk Władysława Jagiełły, Świdrygiełło ustanowił starostą kamienieckim Hryćka Kierdejowicza, który wystąpił z tym

${ }^{6}$ K.J. HŁadylowicz: Zmiany krajobrazu..., s. 105, 109; S. SRoкоwsKi: Zarys geografii fizycznej..., s. 61-62; M. RACIBORSKI: Mapa geobotaniczna ziem polskich i jej objaśnienie. W: Encyklopedia polska. T. 1. Dział I, II: Geografia fizyczna ziem polskich i charakterystyka fizyczna ludności. Kraków 1912, s. 359; M. Koczwara: Rozwój polodowcowej flory i klimatu Podola $w$ świetle analizy pyłkowej. Lwów 1927, s. 51 (Prace Geograficzne Wydawane przez Prof. E. Romera, z. 9: Podole).

7 Rodzinę tę opisał w swej pracy K. PUŁASKI (Ród Kierdejów podolskich..., s. 169-194), lecz dziś jest ona zdecydowanie niewystarczająca, np. Hryćka Kierdejowicza, starostę kamienieckiego, i jego syna Jana Hryćka z Pomorzan, wojewodę podolskiego, autor potraktował jako tę samą osobę, co generowało kolejne błędy. Te liczne błędy genealogiczne prostował już A. Boniecki: Herbarz Polski. Cz. 1: Wiadomości historyczno-genealogiczne o rodach szlacheckich. T. 10. Warszawa 1907, s. 41-46.

Na Wołyniu już w XIV w. działało wielu przedstawicieli tej rodziny. Jako pierwsi pojawili się Olizar i Waśko Kierdejowicze, którzy w 1358 r. uczestniczyli w rozgraniczeniu Mazowsza i Litwy. W 1387 r. Waśko Kierdejowicz poręczał królowi za Olechnę Dmitrowicza, a Świdrygiełło w nieznanym czasie nadał Piotrowi Wańkowiczowi Kierdejowiczowi Mylskiemu dobra w ziemi łuckiej (K. PuŁaski: Ród Kierdejów podolskich..., s. 172; CE, T. 1, nr 11; Inventarium, s. 271; A. Boniecki: Herbarz Polski..., s. 41). Rozrodzeni potomkowie wołyńskich Kierdejowiczów byli protoplastami wielu znanych rodzin na Wołyniu i Litwie: Czapliców, Kozińskich, Dziusów, Hośckich, Mylskich, Olizarów-Szyłowiczów, Wielhorskich, Mniszyńskich, Krzyczowskich (K. PuŁaski: Ród Kierdejów podolskich..., s. 172; K. Niesiecki: Herbarz polski powiększony dodatkami z późniejszych autorów, rękopismów, dowodów urzędowych. Wyd. J.N. Bobrowicz. T. 5. Lipsk 1840, s. 80-81; S. Uruski: Rodzina. Herbarz szlachty polskiej. T. 6. Warszawa 1909, s. 319; A. Boniecki: Herbarz Polski..., s. 41-42).

${ }^{8}$ Najstarsze dokumenty dla franciszkanów kamienieckich z lat 1400 i 1402 . Wyd. J. KuRtyka. W: J. Kurtyka: Podole w czasach jagiellońskich. Studia i materiaty. Oprac. M. WiLAMOWSKI. Kraków 2011, Aneks, nr 1.

9 AGAD, MK 71, k. 28-29; Najstarsza księga miejska (1382-1389). Wyd. A. CzoŁowSKI. Lwów 1892 (Pomniki Dziejowe Lwowa z Archiwum Miasta, T. 1), nr 606.

${ }_{10}$ ZDM, Cz. 1, nr 237. 
urzędem na dokumencie księcia dla klasztoru Dominikanów w Kamieńcu z 17 sierpnia 1400 roku $^{11}$. Po buncie Świdrygiełły na przełomie 1401 i 1402 roku Jagiełło wezwał do Wiślicy starostę kamienieckiego Hryćka, który 23 czerwca 1402 roku złożył królowi przysięgę wierności i zobowiązał się przekazać Kamieniec oraz inne podolskie zamki Dziersławowi Konopce z Kożuchowa ${ }^{12}$. Tym samym Kierdejowicz, odstąpiwszy od Świdrygiełły, przeszedł na stronę polską i związał się ściśle z królem. W nagrodę 23 sierpnia 1404 roku Hryćko otrzymał od polskiego władcy 100 kop groszy praskich zapisanych na bani (żupie) w Gwoździcy w ziemi halickiej ${ }^{13}$. Był to pierwszy znany, bezpośredni związek majątkowy Kierdejowicza z Rusią Koronną (nie licząc niejasnych powiązań z końca XIV wieku). Dnia 19 października 1404 roku w Medyce Hryćko wszedł w skład sądu polubownego. Sąd ten, składający się z 38 i więcej przedstawicieli rycerstwa polskiego oraz bojarstwa ruskiego, na czele $\mathrm{z}$ wojewoda krakowskim i starostą ruskim Janem z Tarnowa, podkomorzym krakowskim Gniewoszem z Dalewic i podczaszym sandomierskim Florianem z Korytnicy, miał rozstrzygnąć spór między królem a Jadwigą, wdową po Ottonie z Pilicy, i ich córką Elżbietą, żoną Wincentego z Granowa, o miasto Tyczyn z kluczem (dystryktem) Zalesie w ziemi sanockiej, które Otton kupił za 500 grzywien. Sędziowie uznali, że monarcha ma większe prawo do tych dóbr, i przysądzili mu je po uprzednim wypłaceniu przez niego wdowie i jej córce tych 500 grzywien. Dla gwarancji wyroku sędziowie przyjęli od Jagiełły pamiętne, na Rusi zwane pomocnym (pomoczne) ${ }^{14}$. Udział w rozsądzeniu takiego sporu świadczy o wysokiej pozycji Kierdejowicza wśród elity rycerskiej na Rusi. W 1410 roku król nadał Hryćkowi wsie Kormilce i Chodykowce na Podolu ${ }^{15}$.

${ }^{11}$ Annales, lib. 10 [1985], s. 254-255; Najstarsze dokumenty dla franciszkanów kamienieckich..., Aneks, nr 1; Z. WDowiszewski: Genealogia Jagiellonów i domu Wazów w Polsce. Kraków 2005, s. 38, 45; J. TęGowski: Pierwsze pokolenia Giedyminowiczów. Poznań-Wrocław 1999, s. 61, 156, 241; J. Kurtyka: Wstep. W: UrzPod, s. 12-13; Tenże: Podole w średniowieczu i okresie nowożytnym. Obrotowe przedmurze na pograniczu cywilizacji. W: TenżE: Podole w czasach jagiellońskich..., s. 120-121 (tu szerzej na temat dat panowania Świdrygiełły na Podolu); F. SiKora: Starostwo szydtowskie z jurysdykcja grodzka w latach 1394-1438. „Archaeologia Historica Polona” 2005, T. 15, z. 2, s. 141; J. SzYsZKA: Kształtowanie się podziałów terytorialnych Rusi Czerwonej na przykładzie ziemi lwowskiej. W: „Średniowiecze Polskie i Powszechne". T. 3 (7). Red. J. Sperka, B. Czwojdrak. Katowice 2011, s. 134; J. Szyszka: Formowanie i organizacja dóbr monarszych $w$ ziemi lwowskiej od połowy XIV do początku XVI wieku. Kraków 2016, s. 138-139.

${ }^{12}$ CE, T. 2, nr 26; A. Prochaska: Podole lennem Korony 1352-1430. RAUhf 1895, Seria 2, T. 7 (32), s. 269-270; O. HaLecki: Dzieje Unii Jagiellońskiej. T. 1. Kraków 1919, s. 173-174; J. Kurtyka: Podole w średniowieczu..., s. 121.

${ }_{13}$ ZDM, Cz. 6, nr 1666; J. Kurtyka: Podole w średniowieczu..., s. 121.

${ }^{14} \mathrm{KDM}$, T. 4, nr 1084; zob. też A. Fastnacht: Slownik historyczno-geograficzny ziemi sanockiej w średniowieczu. Cz. 3. Do druku przygotowali A. Fastnacht-StuPnickA, A. GĄSIOROWSKI. Kraków 2002, s. 199.

${ }^{15}$ Hruszewski, nr 14; J. Kurtyka: Podole w średniowieczu..., s. 121. 
Hryćko Kierdejowicz po raz ostatni wystąpił w źródłach 15 sierpnia 1414 roku ${ }^{16}$. Prawdopodobnie zmarł wkrótce potem. $Z$ pewnością nie żył już jakiś czas przed 30 maja 1423 roku, kiedy potwierdzono umowę podziałową jego synów ${ }^{17}$. W 1417 roku niejaki Hryćko pozwał rajców lwowskich, którzy mieli udać się przed oblicze króla do Glinian, lecz nie wiadomo, czy był to syn Kierdejowicza - również Hryćko, czy inny człowiek o tym imieniu ${ }^{18}$. Dnia 29 września 1422 roku Witold poczynił zapis Januszowi Kierdejowi na osadzonej przez niego wsi Nowa Ruda na Podolu. Zasiedlenie osadnikami wymagało wiele czasu, więc można przypuszczać, że Janusz Kierdej samodzielnie gospodarował tą osadą już od kilku lat. Wprawdzie można założyć, że ojciec wydzielił wcześniej Januszowi jakieś dobra, jednak w połączeniu z brakiem wystąpień Hryćka bardziej prawdopodobne jest, że nie żył on już na długo przed tą datą. Zatem wydaje się, że przynajmniej od ok. 1420 roku synowie Hryćka samodzielnie gospodarowali dobrami, a on już wówczas nie ży $1^{19}$. Kierdejowicz, wywodząc się z rodzimego ruskiego bojarstwa, przeszedł na konfesję rzymską. Być może uczynił to za sprawą żony Klary, znanej tylko z imienia, które jest charakterystyczne dla osób z łacińskiego kręgu kulturowego. Oboje z żoną zostali bowiem pochowani w kościele Bożego Ciała OO. Dominikanów we Lwowie ${ }^{20}$. Ich potomkowie zachowali dbałość o ich pamięć i bliskie związki z klasztorem, o czym dalej.

4. Hryćko Kierdejowicz, oprócz wspomnianych Kormilców, Chodykowców i zapisu na bani w Gwoździcy, posiadał wiele innych dóbr na Podolu, w ziemiach halickiej i lwowskiej, co wynika ze składu masy spadkowej z czasu podziału ojcowizny przez jego synów. Był właścicielem wsi: Ortów na Podolu bracławskim; Orynin, Rybyńce, Szmankowce, Stary Jarosław oraz zastawu na Uściu i Ćwikłowicach na Podolu; Choceń, Studzianka, Dobrawódka, Mikulińce, Podwysokie i Hruszów w ziemi halickiej; Pomorzany, Bóbrczany, Hodów, Plichów, Snowicz, Szpikłosy, Urmań, Żabin, Złoczów i Winniki w ziemi lwowskiej ${ }^{21}$. Pewna część tych dóbr znalazła się w rękach Hryćka dzięki nadaniom królewskim lub książęcym. Nie wiadomo, w jaki sposób Kierdejowicz wszedł w posiadanie Chocenia, Studzianki, Dobrawódki, Mikulińców, Pod-

16 ZDM, Cz. 6, nr 1786.

17 AGAD, Tzw. Metryka Litewska, sygn. IV. B. 9 [Księga wpisów przywilejów na dobra W województwie ruskim przedkładanych podczas „,rewizji listów” w 1563/1564] (dalej: Rewizja Listów 1564), k. 353v-354.

18 Ksiega przychodów i rozchodów miasta (1414-1426). Wyd. A. CzoŁowski. Lwów 1905 (Pomniki Dziejowe Lwowa z Archiwum Miasta, T. 3), s. 34-35, nr 163.

${ }^{19}$ Repertorium podolskie dokumenty do 1430 roku. Oprac. J. KurTyKA. W: J. KurtykA: Podole w czasach jagiellońskich..., nr 133, 156; Hruszewski, nr 18.

20 AGZ, T. 2, nr 70 (w edycji wydawca opuścił imię żony Hryćka); Archiwum Polskiej Prowincji Dominikanów w Krakowie (dalej: ArchDomKr), sygn. Lw. 024 [oryginał pergaminowy].

${ }^{21}$ Rewizja Listów 1564, k. 353v-354. 
wysokiego, Hruszowa, Orynina, Rybyńców i Ortowa. Natomiast z protokołu rewizji dokumentów przeprowadzonej w 1469 roku dowiadujemy się, że Stary Jarosław i Szmankowce na Podolu otrzymał z donacji, choć nie wiadomo, kto i kiedy je nadał. Pewne jest tylko, że nadanie Starego Jarosławia zostało spisane w języku ruskim, a Szmankowców w łacińskim ${ }^{22}$.

Dobra pomorzańskie w ziemi lwowskiej nadał „wieczyście” (donatio perpetua) bez wątpienia Władysław Jagiełło przed 1423 rokiem. Jednak nie ma pewności, czy odbiorcą nadania był Hryćko Kierdejowicz, czy też ktoś inny, od którego potem zakupił ten majątek ${ }^{23}$. Tym samym trudno stwierdzić, kiedy Hryćko wszedł w posiadanie tych dóbr. Z pewnością był to majątek, który objął sam przed śmiercią, gdyż potem wszedł on w skład substancji spadkowej. W krótkim i lakonicznym streszczeniu dokumentu nadawczego (littera perpetua) spośród tych osad wymienione z nazwy są jedynie: Pomorzany, Plichów i Snowicz (ryc. 1), choć wyraźnie zaznaczono, że z innymi przyległościami (et aliis coherentibus), co w tym źródle nie jest zbyt częste i może oznaczać, że oprócz wspomnianych punktów osadniczych w dokumencie były zapisane jeszcze inne, których autor streszczenia nie wymienił. Ponadto ze źródła wiadomo, że odbiorca mógł sprzedać te dobra jedynie za zgodą królewską (de scitu regio vendendis). On i jego spadkobiercy mieli obowiązek stawiać się na każdą wyprawę wojenną z jedną kopią i pięcioma strzelcami ${ }^{24}$. Liczba strzelców świadczy o tym, że dobra przynosiły wysokie dochody, a zatem mogły być dobrze rozwinięte gospodarczo lub rozległe terytorialnie. Zważywszy na stan rozwoju gospodarczego tego obszaru na początku XV wieku (brak miast lokacyjnych, urządzeń gospodarczych i źródeł surowców kopalnych), wydaje się, że o potencjalnej wartości decydowała jednak rozległość dóbr. W określeniu brakujących składowych nadania pomorzańskiego pomocny jest

${ }^{22}$ Bona Regalia Onerata in Terris Russiae etc. Lustratio 1469 r. W: Polska XVI wieku pod względem geograficzno-statystycznym. T. 7. Cz. 1.B: Ziemie ruskie. Ruś Czerwona. Wyd. A. JabŁONOWSKi. Warszawa 1902 (dalej: BRO), s. 53 (Źródła Dziejowe, 18).

${ }^{23}$ W 1396 r. na liście świadków dokumentu wystawionego w Strzeliskach (w ziemi lwowskiej) w języku ruskim przez Gniewosza, starostę halickiego, trembowelskiego i żydaczowskiego, poświadczającego wykup 50 kop groszy posagu przez Klusa od swojej teściowej Marii, oprawionego zgodnie z prawem ruskim na Rozworzanach w ziemi lwowskiej, obok innych bojarów ruskich wymieniony został niejaki Kmitka Pomorański, który zapewne też był Rusinem (А.М. Молдован: Пять новонайденных украинских грамот конца XIV - начала XV в. В: Лингвістическое Источниковедение и исторя русского яазыка. Москва 2000, s. 269-270; Katalog dokumentów pergaminowych ze zbiorów Tomasza Niewodniczańskiego w Bitburgu. Oprac. J. Tomaszewicz, M. ZdAnek. Red. W. Bukowski. Kraków 2004 (dalej: KatBit), nr 32 (regest); J. SzyszKa: Formowanie i organizacja..., s. 116). Nie wiadomo jednak, czy jego nazwisko odnosi się do tych Pomorzan, gdyż podobnych nazw również na terenie Rusi halickiej było więcej. Tak rozległe nadanie dla drobnego ruskiego bojara, jakim zapewne był Kmitka, także wydaje się mniej prawdopodobne niż nadanie tych dóbr bezpośrednio zasłużonemu i wysoko sytuowanemu bojarowi Hryćkowi z zamożnej rodziny Kierdejowiczów.

${ }^{24}$ BRO, s. 53; J. SzYszKa: Formowanie i organizacja..., s. 115-116. 


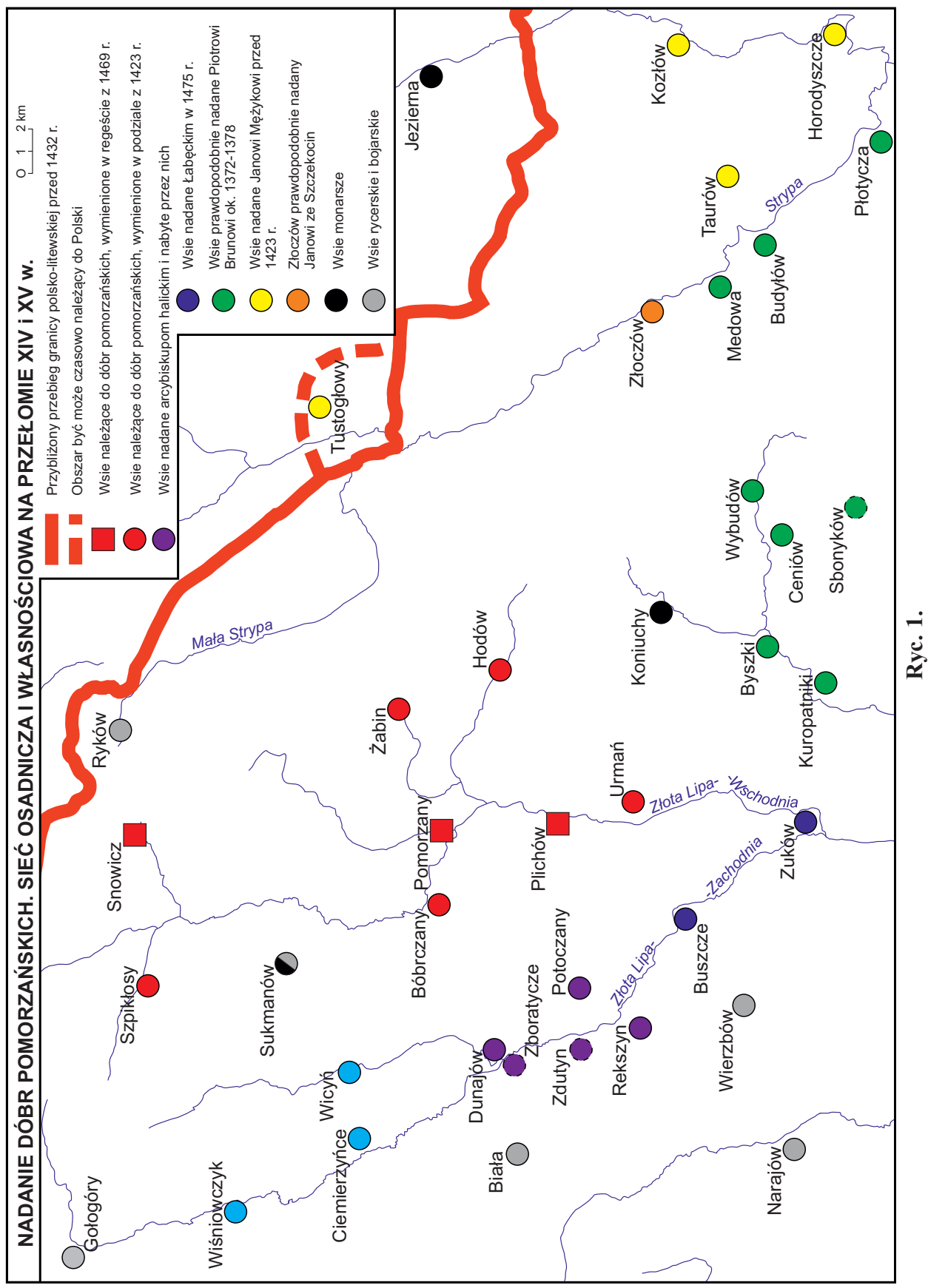


wspomniany wcześniej dokument podziałowy synów Hryćka Kierdejowicza, sporządzony niedługo później. Znamy go z treści potwierdzenia, które 30 maja 1423 roku na polecenie króla wystawili komisarze: Jan Rzeszowski, arcybiskup lwowski, Jan Biskupiec, biskup chełmski, i Wawrzyniec Zaremba, marszałek dworu królewskiego ${ }^{25}$. Oprócz wsi wymienionych w streszczeniu dokumentu donacyjnego $\mathrm{w}$ podziale znalazło się jeszcze siedem miejscowości leżących w ziemi lwowskiej. Pięć z nich należało do dóbr pomorzańskich, gdyż położone były w bezpośrednim sąsiedztwie lub niewielkiej odległości od siebie w dolinie rzeki Złotej Lipy Wschodniej lub jej dopływów (Szwaryca, Biała Wierzba, Żarniec). Oprócz Pomorzan, Plichowa i Snowicza były to: Bóbrczany, Hodów, Szpikłosy, Urmań i Żabin, czyli owe przyległości niewymienione z nazwy w streszczeniu nadania. Wspomniane tam Winniki leżące pod Lwowem z pewnością nie wchodziły w skład tego klucza. Wątpliwości można mieć co do Złoczowa nad Strypą (późniejszej Złoczówki) — wprawdzie nie leży on tak daleko od centrum klucza jak Winniki, ale jednak od doliny Złotej Lipy dzieli go dość znaczna odległość $(18 \mathrm{~km})$ oraz bariera osadnicza w postaci biegnących południkowo wzniesień oddzielających doliny Złotej Lipy i Strypy. Wydaje się więc, że Złoczów należał już do osobnej ekumeny osadniczej usadowionej wzdłuż doliny Strypy i uchodzących do niej potoków. Tym bardziej że w 1410 roku należał do Jana ze Szczekocin, kasztelana wiślickiego, a następnie lubelskiego i starosty halickiego (1408 - 1410), który nawet pisał się z tej wsi w czasie swego pobytu na Rusi ${ }^{26}$. Prawdopodobnie Jan Szczekocki, aktywnie działający na tym obszarze, otrzymał ową wieś z rąk królewskich. Złoczów leżał nad Strypą na pograniczu ziem lwowskiej i halickiej, a zatem w pobliżu zarządzanego przez niego starostwa. Nadawanie dóbr i całych kompleksów majątkowych na Rusi starostom ziem ruskich było w tym czasie powszechną praktyką. W takiej sytuacji był także Jan ze Szczekocin, który wywodził się z małopolskiego rycerstwa i nie posiadał tam wcześniej dóbr ${ }^{27}$. Po powrocie do Małopolski, gdzie otrzymał kolejne urzędy, Szczekocki mógł chcieć pozbyć się dóbr czerwonoruskich, dlatego Hryćko Kierdejowicz zapewne nabył Złoczów z rąk Szczekockiego w latach 1410-1414/1420.

${ }^{25}$ Rewizja Listów 1564, k. 353v-354.

${ }^{26}$ Hruszewski, nr 14; UrzMp, nr 535, 1102; UrzRus, nr 327 (z wieloma błędami — brak wystąpień 30 marca 1410 r. - ZDM, Cz. 6, nr 1736; Repertorium podolskie..., nr 85). Być może był także starostą podolskim (UrzPod, nr 533).

${ }^{27}$ L. EHRLich: Starostwa w Halickiem w stosunku do starostwa lwowskiego w wiekach średnich (1390-1501). Lwów 1914 (Studya nad historyą prawa polskiego, 6), s. 43; K. GóRSKI: Jan ze Szczekocin. W: PSB, T. 10, s. 483; UrzMp, nr 1402; J. LABERSCHeK: Początki i rozwój miasta Szczekociny do końca XV w. Uwagi do genealogii Szczekockich herbu Odroważ. W: Patientia et Tempus. Ksiega jubileuszowa dedykowana Doktorowi Marianowi Korneckiemu. Kraków 1999, s. 109-110; F. SiKORA: Kilka uwag o konflikcie zbrojnym węiersko-polskim w 1410 r. „Rocznik Naukowo-Dydaktyczny WSP w Krakowie. Prace Historyczne” 1987, z. 109, s. 106, 113-114; J. SzyszKa: Formowanie i organizacja..., s. 115-116, 125-126. 
5. Wschodnia część ziemi lwowskiej była pod koniec XIV wieku raczej słabo zasiedlona. Osadnictwo skupiało się głównie w dolinach rzek, rozchodząc się z czasem w górę ich biegów. Przy czym wydaje się, że było ono znacznie gęściejsze w dolnych partiach dolin rzek Podola Zachodniego, mających swe źródła na południowych stokach pasm Gołogór i Woroniaków, oraz płynących w kierunku południkowym ku Dniestrowi, czyli: Gniłej Lipy (zachodniej) z jej dopływem Narajówką, Złotej Lipy w jej głównym biegu wraz z jej górnymi odnogami (Złotą Lipą Zachodnią z jej dopływem Gniłą Lipą, inaczej Kropiwną, oraz Złotą Lipą Wschodnią, płynącą przez Pomorzany z jej dopływami) oraz Strypy z jej dopływem Wosuszką ${ }^{28}$.

Na tym obszarze na przełomie XIV i XV wieku przeważała własność monarsza, która wówczas stała się przedmiotem intensywnej akcji donacyjnej władców (zob. ryc. 1). Większość nadań obejmowała ekumeny osadnicze dolin rzecznych. Najwcześniej wzmiankowanymi osadami w tym regionie są Leśniki i Cześniki leżące już w ziemi halickiej, lecz na pograniczu z ziemią lwowską, które w 1368 roku Kazimierz Wielki nadał Stanisławowi Drzewięcie z Borku ${ }^{29}$. Były one jednak znacznie oddalone od Pomorzan. W 1375 roku Władysław Opolczyk nadał na prawie lennym Jaszkowi Cewlejce i Jakuszowi z Łabęd wsie Buszcze i Żuków nad Złotą Lipą Zachodnią, leżące znacznie bliżej dóbr pomorzańskich, oraz Duszanów w dolinie Gniłej Lipy. Wówczas nadał też Mikołajowi Słęce Potoczany leżące na północ od Buszcza w dolinie Złotej Lipy Zachodniej ${ }^{30}$. W tym czasie Piotr Brun, sędzia prowincji ruskiej,

${ }^{28}$ Nazewnictwo rzek w tej części ziemi lwowskiej jest chaotyczne, gdyż istnieją w niedalekiej odległości dwie rzeki o nazwie Gniła Lipa i dwie o nazwie Złota Lipa, które zresztą łączą się, tworząc „właściwą" Złotą Lipę. Sytuację próbowano uporządkować nieco w: SG, T. 5, s. 249-251, gdzie: a) Gniła Lipa wypływająca koło Lipowców i uchodząca do Dniestru na południe od Halicza nazwana jest Gniłą Lipą, b) Gniła Lipa, lewy dopływ Złotej Lipy Zachodniej, wypływająca koło Żukowa, nazwana jest Gniłą Lipą, inaczej Kropiwną, c) Złota Lipa wypływająca koło Majdanu Gołogórskiego i łącząca się z inną Złotą Lipą na północ od Hinowic nazwana jest Złotą Lipą Zachodnią, d) Złota Lipa wypływająca na zachód od Szpikłosów i łącząca się ze Złotą Lipą Zachodnią na północ od Hinowic nazwana jest Złotą Lipą Wschodnią, e) Złota Lipa od momentu połączenia obydwu rzek aż do jej ujścia do Dniestru nazwana jest po prostu Złotą Lipą. Podobne nazewnictwo stosują wydawcy Mapy Miega: Galicja na józefińskiej mapie topograficznej 1779-1783. Wyd. Z. BudzyŃsKi. T. 12. Cz. A; T. 13. Cz. A. Warszawa 2016-2018 - tu: T. 12. Cz. A, s. 46, 49, 87-88 (przyp. 351, 382, 682, 686, 689), którzy operują nazwą Gniła Lipa, Gniła Lipa (wschodnia), Złota Lipa (zachodnia), Złota Lipa (wschodnia; dziś ukr. Schidna Zolota Lypa). Dla zachowania porządku w tym miejscu będzie używana terminologia z SG, choć nie stosuje się jej na żadnych mapach topograficznych średnio- i wielkoskalowych.

${ }^{29}$ KDM, T. 3, nr 816; J. Szyszka: Formowanie i organizacja..., s. 79.

${ }^{30}$ BCzart., dok. perg. 170; AGZ, T. 2, nr 6; J. Sperka: Otoczenie Władysława Opolczy$k a w$ latach 1370-1401. Studium o elicie wladzy w relacjach z monarcha. Katowice 2006, s. 280-281, 296-297; TenżE: Władysław ksiązę opolski, wieluński, kujawski, dobrzyński, pan Rusi, palatyn Wẹgier i namiestnik polski (1326/1330—8 lub 18 maja 1401). Kraków 2012, s. 353; J. SzyszKa: Formowanie i organizacja..., s. 99. 
jeden z najbliższych współpracowników Opolczyka, był właścicielem klucza wsi położonych nad górnym biegiem rzeki Ceniówki - lewego dopływu Złotej Lipy (Kuropatniki, Byszki, Ceniów i Wybudów). Druga część tych dóbr leżała dalej na wschód, nad brzegiem Strypy, za grzbietem dzielącym ją od dorzecza Złotej Lipy (Medowa, Budyłów i Płotycza), a nawet na wschód od Strypy (Taurów). Piotr Brun, przybywszy na Ruś wraz z Władysławem Opolczykiem, nie posiadał tu dziedzicznego majątku, zatem najpewniej otrzymał te wsie z nadania książęcego ${ }^{31}$. Dokument królowej węgierskiej Marii z 1382 roku potwierdzał, że Barbara, żona Waśka Brody z Żurawna, i Kryza - córki Piotra Bruna, były jego dziedziczkami i miały prawo do jego dóbr ${ }^{32}$. W 1386 roku Opolczyk nadał rycerzowi Denhartowi wieś Dunajów wraz z cłem, położoną nad Złotą Lipą Zachodnią w sąsiedztwie dóbr pomorzańskich. Następnie osada trafiła w ręce arcybiskupów halickich, być może przekazana przez owego Denharta, pochodzącego zapewne spoza Rusi i Polski, który po nieudanym powrocie Opolczyka może nie wiązał z Rusią swej przyszłości ${ }^{33}$. Arcybiskupi rozpoczęli tam budowę klucza majątkowego. W 1404 roku król zezwolił im na wykopanie stawu na Wielkiej Lipie (Złotej Lipie Zachodniej) i wzniesienie młyna na granicy z wsią królewską Zboratycze (dziś nieistniejącą), którą nadał im rok później ${ }^{34}$. W 1424 roku zezwolił im na lokację miasta na prawie magdeburskim w Dunajowie oraz nadał wsie królewskie Rekszyn i Zdutyn (dziś nieistniejący), położone na południe od Dunajowa nad Złotą Lipą ${ }^{35}$. Ponadto w tym rejonie w 1389 roku Jagiełło nadał Mikołajowi z Gołogór wsie Wicyń i Ciemierzyńce, położone nieco na północ od Dunajowa nad Złotą Lipą Zachodnią i Gniłą Lipą (Kropiwną) ${ }^{36}$.

6. Od wschodu z dorzeczem Złotej Lipy Wschodniej, gdzie leżały dobra pomorzańskie, sąsiadowało skupisko osadnicze umiejscowione w dolinie górnej Strypy z dopływami (Małą Strypą i Wosuszką). Większość osad (wspomnianych do 1423 roku) położona była po wschodniej stronie Strypy. Na zachodnim brzegu leżały tylko: Medowa, Płotycza i Budyłów, należące do wspomnianego klucza ceniowskiego, oraz Złoczów będący w 1410 roku w posiadaniu Jana ze Szczekocin (zob. dalej). Natomiast cztery osady ulokowane po wschodniej

31 J. SPerka: Otoczenie Władysława Opolczyka..., s. 311-315; J. SzyszKa: Formowanie i organizacja..., s. 99.

32 AGAD, MK 55, k. 263-264v (regest: MRPS, T. 4, Suppl., nr 308, 310). Dokument królowej Marii został na prośbę Waśka z Żurawna potwierdzony przez Władysława Jagiełłę w latach 1387-1391.

33 AGZ, T. 2, nr 14, 15, 31; J. Sperka: Otoczenie Wtadysława Opolczyka ..., s. 214; TenżE: Władysław ksiażę opolski..., s. 354; J. SzYsZKa: Formowanie i organizacja..., s. 100, 121, 339, 351. Maciej Wilamowski (Jakub Strepa. W: PSB, T. 44, s. 321) uważa, że król nadał tę wieś arcybiskupstwu halickiemu w latach 1387-1398.

${ }^{34}$ AGZ, T. 2, nr 31, 32.

35 Tamże, nr 43; T. 3, nr 97.

${ }^{36}$ AGZ, T. 2, nr 19. 
stronie Strypy: Tustogłowy leżące prawdopodobnie nad Małą Strypą (w dokumencie z 1423 roku nazwaną rzeka Horodyszcze ${ }^{37}$ ), Krasne, Taurów i Horodyszcze nad Wosuszką, należały przed 1423 rokiem do Jana Mężyka z Dąbrowy herbu Wadwicz ${ }^{38}$. Nie mając wcześniej żadnych majątkowych związków z Rusią, nie mógł on odziedziczyć po swych przodkach dóbr na pograniczu lwowsko-trembowelskim. Mógł je wprawdzie kupić, lecz prawdopodobnie jak w wielu podobnych przypadkach — został nimi obdarowany przez króla ${ }^{39}$. Oprócz owych dóbr Jan Mężyk posiadał w tym rejonie jeszcze wieś, w dokumencie z 1423 roku nazwaną Rosiscze (najpewniej Różyska w powiecie trembowelskim), którą zamienił za Złoczów z synami Hryćka Kierdejowicza ${ }^{40}$.

Jan Mężyk, zamieniając Różyska na Złoczów (wraz z okolicą, w której istniała zapewne już wtedy wzmiankowana 16 lat później Glinna ${ }^{41}$ ), nabył dobra leżące w tym samym skupisku osadniczym nad Strypą, co reszta jego majątku, położone $5 \mathrm{~km}$ od Krasnego i Taurowa, a zatem przedstawiające dla niego

${ }^{37}$ Istnieją wątpliwości co do identyfikacji Tustogłowów z tego dokumentu z miejscowością o tej nazwie leżącą nad Małą Strypą, gdyż to terytorium przed 1432 r. należało do wołości oleskiej będącej częścią Litwy. Był to teren przygraniczny, więc być może w momencie nadania (przed 1423 r.) Tustogłowy należały do Królestwa, a później zdobyli je Litwini (zob. ryc. 1). Z pewnością nie ma dalszych śladów przynależności owej osady do pozostałych dóbr tego klucza (Kozłów, Olszanka, Krasne, Grodzisko, Pokropiwna, Taurów), który po śmierci Mężyka trafił z powrotem w ręce monarsze. Istnieje też możliwość, że Tustogłowy z dokumentu z 1423 r. to nie Tustogłowy nad Małą Strypą, lecz zaginiona później osada o tej samej nazwie położona w pobliżu Horodyszcza. Wówczas źródłowe „Hrodisce Thluste Holowy in fluuio Hrodziscze” trzeba rozumieć jako Horodyszcze i Tustogłowy nad rzeką Horodyszcze, co oznaczałoby, że obydwie osady usytuowane były nad tą samą rzeką (Horodyszcze), a ponieważ wieś Horodyszcze leży nad Wosuszką, to ta rzeka nazwana została Horodyszczem i nad nią należy również szukać Tustogłów.

${ }^{38}$ AGAD, perg. 7258. Był on bliskim współpracownikiem Władysława Jagiełły, rycerzem pochodzenia śląskiego lub łużyckiego, którego ojciec — Hanusz — osiadł pod koniec XIV w. w ziemi wieluńskiej. Zrobił karierę na królewskim dworze i zdobył zaufanie monarchy (F. KiRYK: Mężyk Jan z Dąbrowy. W: PSB, T. 20, s. 513-514; B. CzwoJdrak: Powiazania genealogiczne Hanusza i Jana Mężyka z Dąbrowy herbu Wadwicz z Rogowskimi herbu Działosza i Dlugoszami herbu Wieniawa. W: Społeczeństwo Polski średniowiecznej. Red. S.K. KuczyŃSKI. T. 10. Warszawa 2004, s. 121-123, 126-129).

${ }^{39}$ W 1425 r. król nadał mu klucz 8 wsi w ziemi lwowskiej: Hoszany, Hodwisznię, Koropuż, Chiszewice, Borcz, Doliniany, Ostrów i Czułowice (ZDM, Cz. 7, nr 1891; J. Szyszka: Formowanie i organizacja..., s. 127).

${ }^{40}$ Wieś leżąca nad Zbruczem, znana ze wzmianek w aktach halickich z 1470 i 1473 r. jako własność Jana Świnki z Pomorzan. Poza tym istnieje tu przekonująca bliskość językowa: 1423: Rosiscze - 1470: Roschicze - 1473: Rozyscze (AGZ, T. 12, nr 3619, 4042; J. SzYsZKa: Świnka Jan z Pomorzan (Pomorzański) h. Kierdeja. W: PSB, T. 51, s. 605). Mniej prawdopodobne, że był to Chorościec w powiecie lwowskim (leżący po prawej stronie Strypy), który wzmiankowany jest dopiero w 1504 r. jako częściowo własność Sienieńskich z Gołogór (dziedziców części dóbr pomorzańskich), a częściowo Chomętowskich (AGZ, T. 15, nr 4634).

${ }^{41}$ W 1439 r. król zastawił Glinnę i Złoczów Bohdanowi z Janczyna (ZDM, Cz. 8, nr 2230; J. Szyszka: Formowanie i organizacja..., s. 225-226). 
znacznie większą wartość. Natomiast dobra pomorzańskie Kierdejowiczów, leżące nad Złotą Lipą Wschodnią i jej dopływami, oddzielała od Złoczowa pustka osadnicza rozciągająca się na płaskowyżu między dolinami tych rzek. Ten wspominany często dalej teren to pas ciągnący się południkowo, pofałdowanym grzbietem o łagodnych stokach (zob. ryc. 3). Oddzielał on też od Strypy wspomniane już skupisko nad Ceniówką, lewym dopływem Złotej Lipy, należące wówczas do rodziny Wołczkowiczów (Kuropatniki, Byszki, Ceniów, Wybudów, Sołomków i Sieńków), oraz osady nad potokiem Koniuchy, prawym dopływem Ceniówki (Koniuchy z lasami Koniuszki i Korsów), będące własnością monarchy. Odległość Pomorzan od położonego na południowy wschód od nich Złoczowa wynosi $21 \mathrm{~km}$ w linii prostej (między Hodowem i Glinną, potwierdzonymi w tym czasie źródłowo najdalej wysuniętymi osadami dóbr pomorzańskich i złoczowskich $-13 \mathrm{~km}^{42}$ ). Zatem Złoczów pod względem osadniczym nie należał do dóbr pomorzańskich ani nie sąsiadował z nimi blisko, więc Kierdejowicze zapewne chętnie zgodzili się na zamianę.

Jan Mężyk, zamieniając wspomniane dobra, uzyskał jeszcze od Kierdejowiczów zobowiązanie, że poddani z tych jego osad będą mogli brać drewno na budowę z lasów wsi Pomorzany ${ }^{43}$. Ten fragment dokumentu wnosi ważne informacje w kontekście rekonstrukcji średniowiecznego krajobrazu. Zaświadcza bowiem o niewielkich zasobach leśnych w dobrach Mężyka w dorzeczu górnej Strypy już w początkach XV wieku. Stan zalesienia tego obszaru (na wschód od wododziału Złotej Lipy Wschodniej i Strypy, przebiegającego grzbietem

${ }^{42} \mathrm{O}$ istnieniu szerokich stref granicznych (granic strefowych) w układach o rzadkim osadnictwie zob. T. Figlus: Uwagi na temat procesu kształtowania się granic wsi w Polsce do końca XVIII wieku w kontekście morfogenetycznym. „Studia z Geografii Politycznej i Historycznej” 2015, T. 4, s. 255, 271.

${ }^{43}$ AGAD, perg. 7258. W 1427 r. Władysław Jagiełło wystawił dla mieszkańców Złoczowa przywilej dotyczący korzystania przez nich z królewskiego lasu Koniuszki położonego koło Koniuch nad potokiem Korsów (AGAD, Zbiór Czołowskiego, sygn. 405, s. 36). Najpewniej chodzi o las po wschodniej stronie tego strumienia, porastający zbocza grzbietu oddzielającego dolinę Strypy od dorzecza Złotej Lipy Wschodniej, który częściowo przetrwał jeszcze do XVIII w. (Galicja na józefińskiej mapie..., T. 13. Cz. A, s. 44; Cz. B, sekcja 344). Wówczas odległość ze Złoczowa do tego lasu wynosiła ok. $9 \mathrm{~km}$, ale prawdopodobnie w 1. poł. XV w. sięgał on znacznie dalej na wschód, aż po grań grzbietu, gdzie wznosi się wzgórze Koniuchy (7 km na zachód od Złoczowa), a na północny wschód i południowy wschód od tegoż wzgórza w połowie XIX w. występowały nazwy fizjograficzne pól i łąk takie jak: Za Brzeziną, Na Bereskach, Kąty za Brzeziną, natomiast na początku XX w. istniejąca do dziś osada Zaberezki (Zaberizki), zob. Habsburg Empire (1869-1887) - Third Military Survey (1 : 25000). Dostępne w Internecie: https://mapire.eu/en/map/thirdsurvey25000/ [data dostępu: 19.08.2020] (mapa topograficzna, Keiserlich und Königlich Militaergeografisches Institut, 1:25000 — dalej: Third Military Survey $(1: 25000))$; Mapa topograficzna WIG, $1: 25000$. Warszawa 1934, sekcja P. 50-S. 40-H. O niskim poziomie lesistości tego obszaru świadczy też to, że w 1511 r. kupujący wschodnią część Hodowa Jan Chomętowski, chcąc zapewnić sobie niezbędny do gospodarowania dostęp do lasów, wymógł zagwarantowanie mu przez sprzedającego użytków w lasach Urmania (zob. dalej). 
płaskowyżu), na którym szczegółowe mapy i opisy z 2. poł. XVIII wieku potwierdzają istnienie rozległych łąk z roślinnością stepową, już wtedy był znikomy $^{44}$. Prawdopodobnie tak niewielkie zalesienie nie było wyłącznie efektem drapieżnej deforestacji wskutek antropopresji wynikającej z intensywnej gospodarki człowieka ${ }^{45}$, ale przede wszystkim wiązało się z naturalnie niskim stanem lesistości tego obszaru, na którym istniały dawniej stepy charakterystyczne dla wschodniej części Podola i Ukrainy, w XIX wieku (a być może już wcześniej) stopniowo przekształcane na pola uprawne ${ }^{46}$. Natomiast zalesienie terenów położonych na zachód od grzbietu płaskowyżu leżącego między Złotą Lipą Wschodnią a Strypą było znacząco większe. W okolicy Pomorzan i w całej dolinie tej rzeki oraz jej dopływów lasy były liczne i gęściejsze, porastały zwłaszcza zbocza oraz wierzchowiny płaskowyżów i grzbietów, które poprzecinane były dolinami rzek oraz strumieni.

7. Jeszcze przed wspomnianą zamianą Złoczowa na Różyska, 30 maja 1423 roku pięciu braci Kierdejowiczów dokonało podziału dóbr odziedziczonych po ojcu Hryćku (zob. ryc. 2). Zygmunt otrzymał: Choceń, Studziankę i Dobrawódkę, Mikulińce, Podwysokie i Hruszów w ziemi halickiej; Mikołaj Świnka ${ }^{47}$ :

${ }^{44}$ Wynika z nich, że istniały tam tylko cztery niewielkie zagajniki, w tym dwa młodniki (Gaj — młoda dąbrowa k. Pałuczy Wielkiej; nieopisany lasek Netreba, położony na południe od Pałuczy Wielkiej; wysokopienny brzozowy lasek położony na zboczu Kamiennej Góry na zachód od Złoczówki (Złoczowa) i drugi nieopisany, na południe od poprzedniego), oraz Gaj - wysokopienny las dębowy leżący 1,5 km na północny wschód od Tustogłowów (Galicja na józefińskiej mapie..., T. 13. Cz. A, s. 86, 88-89; T. 12. Cz. A, s. 137).

${ }_{45}$ W 1576 r. na terenie pomiędzy Kaplińcami a Taurowem rósł jakiś las, o wycięcie drzew z którego toczył się wówczas spór, w 1602 r. zaś wzmiankowane jest tam miejsce Popławy seu Berezow, co świadczy, że wcześniej istniał tam brzozowy las, lecz raczej rzadki i niewysoki, gdyż określenie „popławy” oznacza podmokłe pola stepowe. Być może rosnący nieopodal w XVIII w. las Netreba rozciągał się wówczas bardziej na południowy wschód, w kierunku Taurowa (AGAD, Zbiór Czołowskiego, sygn. 405, s. 5; TerrLeop 155, k. 128).

${ }^{46}$ K.J. Headylowicz: Zmiany krajobrazu..., s. 103; M. Raciborski: Mapa geobotaniczna..., s. 359. Między Strypą a Seretem leżały stepy: Pantaliszcze (Pantalicha) i Zazdrość, a między Glinną a Kozłowem rozległe „popławy” (SG, T. 7, s. 845; S. SROKowski: Zarys geografii fizycznej..., s. 61-63; W. PoL: Rzut oka na pótnocne stoki Karpat i przyległe im krainy. Kraków 1851, s. 83-84, 88).

${ }^{47}$ W literaturze od XIX w. utrzymywał się pogląd powtarzany w nowszych publikacjach, że Jan Świnka z Pomorzan i Zielonej należał do rodu Świnków z ziemi dobrzyńskiej i był synem Adama ze Strzyg oraz Zielonej. Wejście w posiadanie Pomorzan przypisuje się jego rzekomemu małżeństwu z córką Hryćka Kierdejowicza, starosty podolskiego. Jana Świnkę z Zielonej h. Świnka, pojawiającego się w dokumencie ks. Siemowita z 1435 r., wystawionym w Żydaczowie, identyfikuje się zaś z Janem Świnką z Pomorzan. Dopiero ujawnienie dokumentów z 1423 r., na których dwukrotnie wystąpił Mikołaj Świnka z Pomorzan, nazwany tam wprost synem Hryćka Kierdejowicza (Mikołaj Świnka wzmiankowany był jeszcze trzykrotnie - w: 1430, 1431 i 1436 r.), poparte argumentem o następstwie Jana Świnki z Pomorzan w dobrach dziedziczonych przez Mikołaja, w pełni wyjaśnia filiację kolejno: Hryćka, Mikołaja Świnki i Jana Świnki (AGAD, perg. 7258; Rewizja Listów 1564, k. 353v-354; B. ZAMORSKI: Kronika Pomorzańska..., s. 11; G. i J. ZIELIŃSCY: Wiadomość historyczna o rodzie Świnków oraz ro- 


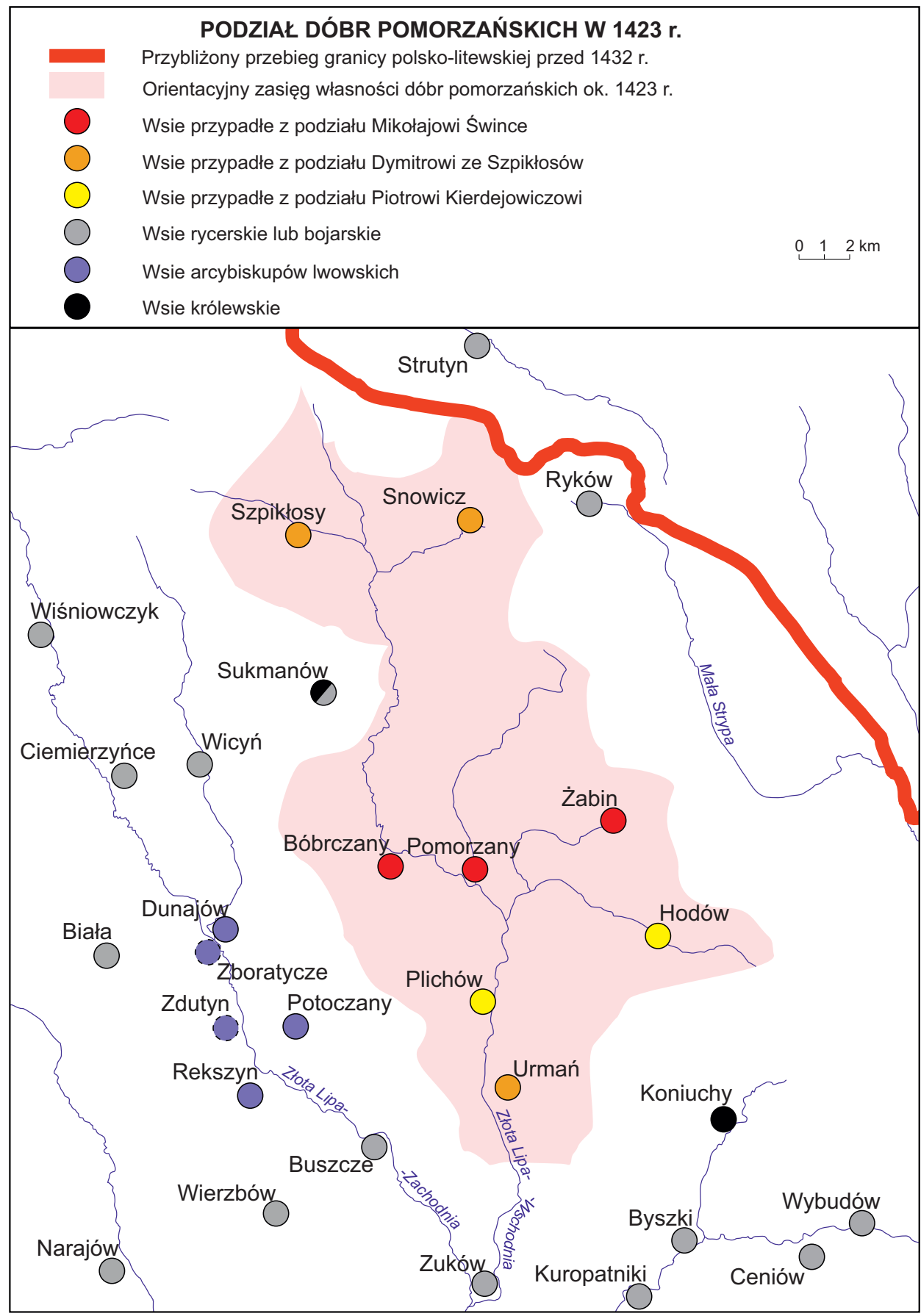

Ryc. 2. 


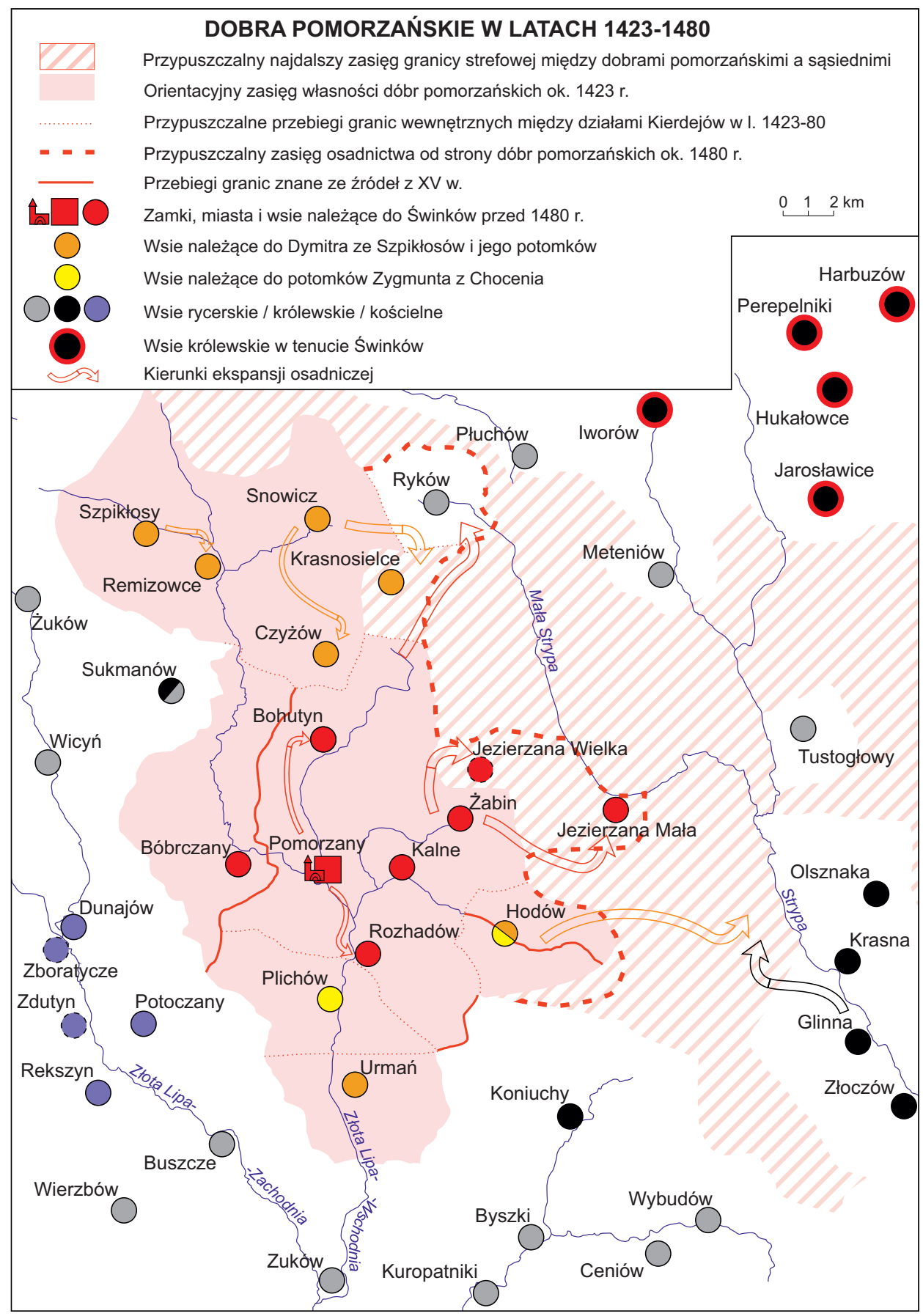

Ryc. 3. 
Pomorzany, Żabin, Złoczów i Bóbrczany w ziemi lwowskiej; Janusz: Orynin, Rybyńce, Uście, Ćwikłowce, Szmankowce na Podolu oraz Ortów (zapewne na Podolu Bracławskim); Dymitr: Szpikłosy, Snowicz i Urmań w ziemi lwowskiej; (Jan) Hryćko: Kormilce, Chudykowce i Stary Jarosław na Podolu oraz dwie niezidentyfikowane wsie Nowa Mschenda i Docholow; Piotr zaś: Hodów, Plichów i Winniki w ziemi lwowskiej ${ }^{48}$. Widać zatem, że dobra pomorzańskie znalazły się w rękach trzech braci: Mikołaja Świnki, Dymitra i Piotra, którzy nie otrzymali żadnych majątków poza ziemią lwowską.

Pomorzany i przynależne do nich dobra pochodzące z podziału w 1423 roku pozostawały w rękach Mikołaja Świnki. Po jego śmierci (między 1436 a 1440 rokiem) przejął je jego syn Jan Świnka, chorąży lwowski (1462-1476) ${ }^{49}$, a po nim z kolei syn Jana Mikołaj Świnka (1476-1479). Co najmniej od 1431 roku z Pomorzan pisał się również brat Mikołaja (Jan) Hryćko, kasztelan lwowski (1434-1438), a potem wojewoda podolski $(1439-1462)^{50}$, który posiadał w ziemi lwowskiej inne dobra dziedziczne oraz wiele tenut i starostw ${ }^{51}$, nigdy jednak nie wystąpił w zapiskach jako dziedzic Pomorzan lub przynależnych do nich dóbr. Możliwe, że nie była to uzurpacja i posiadał on do nich jakieś prawa. Po jego śmierci w 1462 roku z Pomorzan pisali się także jego synowie: Jan (1467-1471) i Zygmunt (1466-1498) Kierdejowicze, starostowie trembowelscy ${ }^{52}$, co dawało podstawę Zygmuntowi do starania się później o spadek po Świnkach, o czym dalej.

Świnkowie trzymali w swoich rękach większość dóbr pomorzańskich. Oprócz najważniejszych osad przynależnej do nich części klucza pomorzańskiego, wymienionych w dokumencie podziałowym z 1423 roku (Pomorzan,

dowód pochodzacych od nich rodziny Zielińskich herbu Świnka. Cz. 1. Toruń 1880, s. 72-74; B. Moż̇ıко: Ród Świnków na pograniczu polsko-krzyżackim w średniowieczu. Gdańsk 1998, s. 212, 215, 222; J. SzyszKa: Formowanie i organizacja..., s. 111, 115; TenżE: Świnka Jan..., s. 604).

${ }^{48}$ Rewizja Listów 1564, k. 353v-354.

49 J. SzYSZKa: Świnka Jan..., s. 604-607; UrzRus, nr 770 — błędne daty urzędowania Jana Świnki.

${ }^{50}$ UrzRus, nr 825; UrzPod, nr 622; F. KiRYK: Kierdej Jan (Hryćko) z Pomorzan. W: PSB, T. 12 , s. 423 .

${ }_{51}$ W ziemi lwowskiej Jan Hryćko z Pomorzan był właścicielem Winnik i Podbereźców koło Lwowa. Dzierżył też starostwo ratneńskie (1431), chełmskie (1431-1438, 1441), krasnostawskie (1433-1462) i trembowelskie (1449-1462) oraz wiele mniejszych tenut jak Kozłów w powiecie trembowelskim lub Zuchorzyce w ziemi lwowskiej (A. BonIECKI: Herbarz Polski..., s. 42-43; UrzRus, nr 664; Urzędnicy betscy i chetmscy XIV—XVIII wieku. Spisy. Oprac. H. Gmiterek, R. Szczygię. Kórnik 1992 (Urzędnicy dawnej Rzeczypospolitej XII-XVIII wieku. Spisy. Red. A. GąSIORowski. T. 3, z. 2: Ziemie ruskie), nr 1407, 1409, 1568; F. KiRYK: Kierdej Jan..., s. 423—424; J. SzysZKa: Formowanie i organizacja ..., s. 115, 254, 463).

52 AGZ, T. 2, nr 107; T. 15, nr 855, 3449, 4567, DXXIX, MCLXIX; BRO, s. 69; MRPS, T. 1, nr 746, 1547; UrzRus, nr 665, 666, 670. 
Żabina i Bóbrczan), należały do nich również wzmiankowane później: Bohutyn (1461), Jezierzana Wielka i Mała (1472), Rozhadów (1477) i Kalne (1479)53. Większość z nich prawdopodobnie istniała już w momencie nadania Pomorzan Hryćkowi Kierdejowiczowi i w czasie podziału z 1423 roku jako niewielkie osady jednodworcze, przysiółki lub uroczyska posiadające swe nazwy miejscowe, lecz jako przynależności nie zostały one wymienione z nazwy w dokumentach. Jan Świnka wchodził też w liczne spory z sąsiadami, w tym ze swym stryjem Dymitrem ze Szpikłosów. W 1442 roku odrzucił jego oskarżenie o najazd na Czyżów (sąsiadujący z Bohutynem od północy). W latach 1453-1454 starosta i wojewoda ruski Andrzej Odrowąż ze Sprowy ustanowił wysoki zakład 500 grzywien w ich sporze o zbiegłych kmieci. W 1443 roku Swinka popadł także w konflikt ze Ściborem z Koniuchów, podsędkiem halickim, który oskarżył go o liczne szkody ${ }^{54}$. W 1461 roku Świnka o mało nie stracił Bóbrczan, gdyż najpierw zastawił tę wieś Mikołajowi z Gołogór, a potem pożyczył od niego jeszcze 60 grzywien pod rygorem ustąpienia własności tej wsi. Widocznie spłacił jednak dług, gdyż Bóbrczany pozostały jego własnością, choć nadal były w zastawie u dziedziców Gołogór. Świadczy o tym fakt, że w 1465 roku król nakazał Śwince stawić się na pozew Katarzyny z Gołogór, córki Mikołaja i żony Andrzeja z Sienna, oraz zapłacić przysądzone jej przezyski, a w 1466 roku Katarzyna otrzymała woźnego do wyegzekwowania swych należności z dóbr Świnki ${ }^{55}$. Był to zwiastun późniejszych długoletnich sporów o dobra pomorzańskie między Sienieńskimi a Kierdejami.

W 1463 roku Jan Świnka nabył za 50 grzywien od swego brata stryjecznego Michała Kierdeja Wojniłowskiego, syna Zygmunta z Chocenia, wsie Plichów i połowę Hodowa, którą jego ojciec otrzymał z podziału z Dymitrem (zob. dalej $)^{56}$. Jednak tylko część Plichowa należała potem do Świnków, zaś druga część tej wsi i Hodowa była później w posiadaniu Mikołaja Kierdeja z Plichowa, zapewne syna Michała ${ }^{57}$. Jan Świnka wykorzystywał również dobra pomorzańskie do kredytowania swej działalności gospodarczej, czego przykładem było zastawienie Bóbrczan Gołogórskich, ale także pożyczka 50 grzywien wzięta od Jadwigi Sieroszowskiej z Rohatyna w 1464 roku pod rygorem wwiązania w połowę Żabina ${ }^{58}$. W 1472 roku Świnka pożyczył od Mikołaja z Zubrzy

53 AGZ, T. 6, nr 45; T. 15, nr 1130, 3834; AGAD, perg. 7357.

${ }_{54}$ AGZ, T. 14, nr 453, 688, 731, 750, 2896, 3787, 3789; J. SzyszKa: Świnka Jan..., s. 605.

55 AGZ, T. 15, nr 3354, 3355.

${ }^{56}$ ADPom. 3 s. 2-3; J. Szyszka: Świnka Jan..., s. 606.

57 AGZ, T. 15, nr 2253, 2254, 2255; T. 19, nr DCCXL; A. Boniecki: Herbarz Polski..., s. 45. Żoną Michała Kierdeja była Anna, siostra Guntera z Sieniawy h. Leliwa, sędziego ziemskiego lwowskiego (K. PuŁaski: Ród Kierdejów podolskich..., s. 15; F. SikORA: Sieniawski Gunter. W: PSB, T. 37, s. 118).

58 AGAD, perg. 7327; J. Szyszka: Świnka Jan..., s. 606. 
60 florenów pod rygorem wwiązania w Wielką i Małą Jezierzanę. Natomiast w 1475 roku Rafał z Jarosławia, starosta ruski, nakazał Śwince zapłacić mieszczaninowi lwowskiemu Mikołajowi Harnastowi 125 grzywien i dać 8 wołów pod rygorem wwiązania w Jezierzanę Wielką i Małą, lecz Świnka nie zapłacił, a do wwiązania nie dopuści ${ }^{59}$. W 1470 roku Jan Świnka sprzedał za 425 grzywien Stanisławowi z Chodcza dobra w powiecie trembowelskim, w tym Różyska, zapewne uzyskane drogą zamiany za Złoczów przez jego ojca Mikołaja w 1423 roku. W 1469 roku Mikołaj Grzymała, instygator królewski, oskarżył Jana Świnkę o bezprawne pobieranie cła w Żabinie i trzymanych w tenucie Jarosławicach $^{60}$.

Jan Świnka rozbudowywał również majątek w pobliżu dóbr pomorzańskich. Między 1442 a 1456 rokiem wykupił od Mikołaja Dawidowskiego z Horpina dobra królewskie Jarosławice i Perepelniki ${ }^{61}$ w powiecie lwowskim, ok. $12 \mathrm{~km}$ na północny wschód od granic dóbr pomorzańskich po przeciwnej stronie doliny Strypy, już w dystrykcie (wołości) oleskim przyłączonym do Królestwa Polskiego dopiero w 1432 roku. W tenucie tej do 1478 roku wzmiankowane były jeszcze Hukałowce, Harbuzów i Iworów ${ }^{62}$. W 1456 roku Jan Świnka wziął w zastaw od Jerzego Łabęty z Żukowa połowę Hinowców, trzecią część sadzawki w Dryszczowie i Żukowie oraz trzecią część młyna w Żukowie za 15 grzywien $^{63}$. Dobra te były przedłużeniem kompleksu pomorzańskiego na południu. Wprawdzie sąsiadowały bezpośrednio z Urmaniem należącym do szpikłoskiej linii Kierdejów oraz z Plichowem należącym do Kierdejów Wojniłowskich, lecz jak wiadomo, Jan Świnka próbował wykupić Plichów. Być może podobne plany miał względem Urmania. Jako właściciel głównego zrębu dóbr pomorzańskich dysponował także dokumentem nadawczym tego klucza, który przedłożył w czasie rewizji praw do dóbr w 1469 roku $^{64}$.

Pomorzany już w momencie nadania (między 1388 a 1423 rokiem) stanowiły centrum osadnicze $\mathrm{w}$ dolinie Złotej Lipy, lecz zapewne dopiero Jan Świnka (a być może jeszcze jego ojciec Mikołaj) rozpoczął tworzenie nowoczesnego klucza majątkowego na wzór tych budowanych już w XIV wieku w Królestwie Polskim, a potem również na Rusi Czerwonej ${ }^{65}$. Najważniejszym

${ }^{59}$ AGZ, T. 15, nr 1130, 1425, 1426.

${ }^{60}$ AGZ, T. 6, nr 79.

${ }^{61}$ ZDM, Cz. 7, nr 2126; AGZ, T. 14, nr 349, 3539; J. Szyszka: Świnka Jan..., s. 606; TenŻE: Formowanie i organizacja..., s. 307.

${ }^{62}$ AGAD, perg. 7361, 7595.

${ }_{63}$ AGZ, T. 19, nr 2756. J. SZYSZKa: Świnka Jan..., s. 606.

${ }^{64}$ BRO, s. 53.

${ }_{65}$ J. WronisZewski: Szlachta ziemi sandomierskiej w średniowieczu. Zagadnienia społeczne i gospodarcze. Poznań-Wrocław 2001, s. 22-25; TenżE: Król jako właściciel ziemski w średniowiecznej Polsce. W: Król w Polsce XIV i XV wieku. Red. A. Marzec, M. WilaMOWSKI. Kraków 2006, s. 120-121; F. SIKORA: Wielkorządy krakowskie na przełomie XIV 
składnikiem takiego klucza było lokowane na prawie niemieckim miasto. Prawdopodobnie w 1456 roku Jan Świnka uzyskał dla Pomorzan zgodę królewską na lokację miasta na prawie magdeburskim ${ }^{66}$, którą następnie przedłożył w 1469 roku w czasie rewizji dokumentów potwierdzających prawa do dóbr ${ }^{67}$. Jednak lokacja Pomorzan nastąpiła znacznie wcześniej, gdyż w 1442 roku osada ta określona została jako civitas, a już w 1439, 1440 i 1444 roku wzmiankowani byli w Pomorzanach wójtowie ${ }^{68}$. W ostatnim dwudziestoleciu $\mathrm{XV}$ wieku informacje o mieście Pomorzany były już na tyle liczne, że nie można mieć wątpliwości co do jego miejskiego charakteru ${ }^{69}$. Najpewniej również Jan Świnka wzniósł w Pomorzanach zamek, którego w 1474 roku dzielnie bronił przed tatarskimi zagonami, co odnotował Jan Długosz ${ }^{70}$. Miasto lokowane na prawie niemieckim i zamek były dwoma składnikami centrum klucza majątkowego, ostatnim zaś był kościół parafialny. W Pomorzanach fundował go najprawdopodobniej Jan Świnka, choć pierwsza wzmianka o nim pochodzi z 1483 roku, kiedy wspomniany został Jakub, pleban z Pomorzan ${ }^{71}$. Tak zbudowane centrum, wraz ze swym wiejskim zapleczem gospodarczym, lasami, stawami i obiektami gospodarczymi, stanowiło kompletny klucz majątkowy.

Należy też zwrócić uwagę, że główny budowniczy majątku pomorzańskiego — Jan Świnka, jako chorąży lwowski odgrywał istotną rolę w lokalnej elicie, o czym świadczy jego przystąpienie do konfederacji lwowskiej w 1464 roku.

i XV wieku. W: Urzędy dworu monarszego dawnej Rzeczpospolitej i państw ościennych. Red. A. Gąsiorowski, R. Skowron. Kraków 1996, s. 103; J. Kurtyka: Odrodzone Królestwo. Monarchia Władysława Łokietka i Kazimierza Wielkiego w świetle nowszych badań. Kraków 2001, s. 145-146; W. Dworzaczek: Leliwici Tarnowscy. Z dziejów możnowładztwa polskiego. Wiek XIV—XV. Warszawa 1971, s. 129, 134-137; J. Szyszka: Formowanie i organizacja..., s. 155.

${ }^{66}$ Informację taką podał B. ZAMORSKi (Kronika Pomorzańska..., s. 11), który powołał się na dokument Zygmunta I z 1520 r. potwierdzający przywilej Jagiellończyka, przechowywany wówczas w archiwum pomorzańskim.

${ }^{67}$ BRO, s. 53.

${ }^{68}$ AGZ, T. 14, nr 30, 454, 1137; KatBit, nr 58; B. ZAmorski (Kronika Pomorzańska..., s. 25) wspomina pod 1437 r. o istnieniu jakiegoś inwentarza Pomorzan, w którym zostały one nazwane oppidum, choć wzmiankę tę należy traktować raczej nieufnie.

${ }^{69}$ AGZ, T. 15, nr 1788, 2380, 2399, 2527, 2565, 2641, 2669, 2836, 4387, 4453, 4557, 45594560, 4573; Najstarsze akta konsystorza lwowskiego. T. 1: (1482-1489). Wyd. W. Rolny. Lwów 1927 (Zabytki Dziejowe, T. 2) (dalej: AC, T. 1), nr 2195, 2399.

${ }^{70}$ Annales, lib. 12 [2005], s. 335; J. Szyszka: Świnka Jan..., s. 606.

${ }^{71}$ AC, T. 1, nr 226. Trudno bez dokładniejszych badań stwierdzić, jakie terytorium objęła parafia w Pomorzanach, ale spośród istniejących w XV w. osad w XVIII w. należały do niej nadal: Rozhadów, Hodów, Bóbrczany, Żabin, Bohutyn, Rzemieniowce, Snowicz, Czyżów, Krasnosielce i Ryków (Z. Budzyński: Kresy poludniowo-wschodnie w drugiej potowie XVIII wieku. T. 2: Atlas geograficzno-historyczny. Przemyśl-Rzeszów 2006, mapa D II-4 36). 
Wystąpił on na akcie jako drugi z kolei po Jerzym Strumile z Dmoszyna, podkomorzym lwowskim ${ }^{72}$.

Jan Świnka z Pomorzan zmarł między 1 marca a 10 czerwca 1476 roku. Miał dwie siostry: Katarzynę, żonę Marcina, tenutariusza Pczan, i Annę, która poślubiła Jana Skarbka z Szarańczuk herbu Abdank. Z żoną Katarzyną, siostrą Macieja Żołędzia z Dryszczowa, miał jeszcze córkę — nieznaną z imienia żonę Marcina z Ostrowa herbu Gozdawa, która urodziła: Andrzeja, Krystyna, Barbarę, Małgorzatę i Michała. Całość dóbr odziedziczył jednak syn Jana Mikołaj Świnka, który pojął za żonę Dorotę, córkę Jana z Sienna i Oleska herbu Dębno, starosty łuckiego i oleskiego ${ }^{73}$. Mąż w 1479 roku oprawił jej 500 grzywien wiana, tyleż posagu i 200 grzywien podarku na dobrach: Pomorzany, Rozhadów, Bóbrczany, Kalne i Bohutyn ${ }^{74}$. Prawdopodobnie w tym czasie jego ciotka Anna Skarbkowa z Szarańczuk skwitowała go z dóbr ojczystych i macierzystych $^{75}$. Na początku Mikołaj musiał zająć się głównie roszczeniami ojcowskich wierzycieli, którzy „ustawiali się w kolejce”76. W 1477 roku zastawił Iwaszkowi Bałabanowi ze Stratyna za 93 grzywny wieś Rozhadów, do której potem nie chciał dać mu wwiązania ${ }^{77}$. Wówczas też $\mathrm{z}$ nakazu starosty miał zwrócić 40 grzywien Michałowi Narajowskiemu, kolejnemu ojcowskiemu wierzycielowi, pod rygorem wwiązania $\mathrm{w}$ Jarosławice ${ }^{78}$, a rok później nie dopuścił do tegoż wwiązania ${ }^{79}$. Lata 1478 - 1479 przyniosły kolejne pozwy i nakazy ciążenia na jego dobrach ${ }^{80}$. Już na początku 1479 roku Mikołaj zobowiązał się oddać Janowi Dawidowskiemu z Nowosielców 25 grzywien pod rygorem wwiązania we wszystkie swoje dobra przynależne do Pomorzan ${ }^{81}$.

Mimo znakomitych koneksji Mikołaja i bardzo dobrych perspektyw rozbudowy dóbr pomorzańskich sytuacja nie ulegała poprawie, a Mikołajowi nie było dane zrealizować ambitnych planów. Zmarł między styczniem 1479 a 9 czerwca 1480 roku $^{82}$. Małżeństwo z Dorotą z Sienna było bezpotomne, zatem jego śmierć rozpoczęła okres intensywnych zmagań o spadek po Świnkach, który stanowił atrakcyjny cel dla zamożnych rodzin ziemi lwowskiej.

${ }^{72}$ AGZ, T. 7, nr 55, 56. Jego pieczęć niestety nie zachowała się wśród pieczęci przywieszonych do tego dokumentu.

73 J. SzYSZKa: Świnka Jan..., s. 606.

74 AGAD, perg. 7357.

${ }^{75}$ AGZ, T. 15, nr 3692 — zapiska jest wydana pod datą 9 września 1474 r., ale mogła tam trafić przypadkiem ze względu na zły stan ksiąg ziemskich lwowskich. Z pewnością dotyczy czasu po śmierci Jana Świnki (1476-1480).

${ }^{76}$ AGZ, T. 15, nr 1507, 1532, 3846; T. 17, nr 3687.

77 AGZ, T. 15, nr 3834, 3844.

78 AGZ, T. 17, nr 3686, 3687, 3688; T. 19, nr 2915, 2917, 2918.

79 AGZ, T. 17, nr 3691-3692.

${ }^{80}$ Tamże, nr 3702-3703; T. 15, nr 3875, 3913, 3926.

81 AGZ, T. 15, nr 3997.

${ }^{82}$ Tamże; AGAD, perg. 7361. 
Kierdejowie - potomkowie Hryćka Kierdejowicza (wybór)

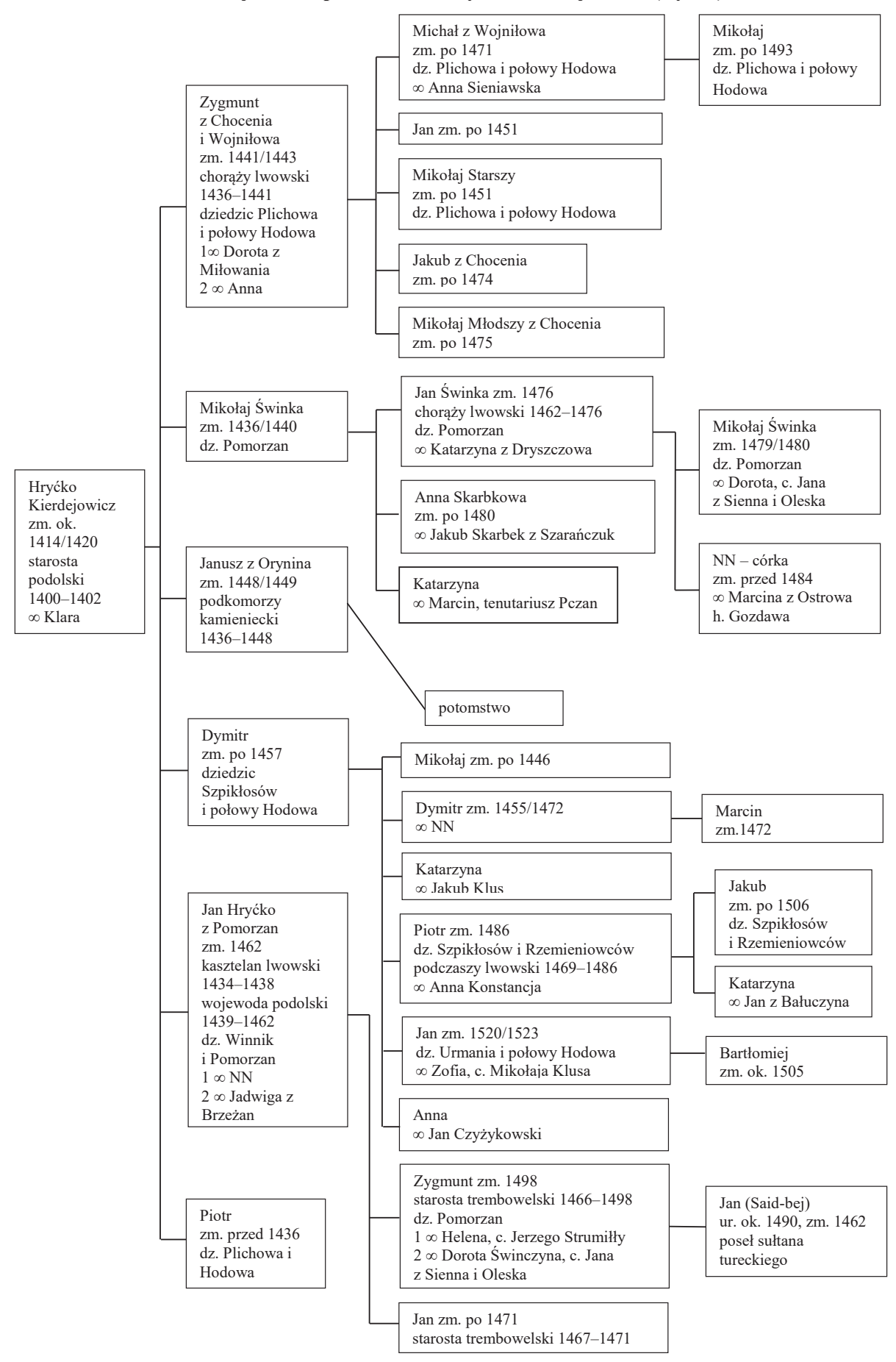


Podział dóbr pomorzańskich z 1423 roku okazał się dość trwały, z wyjątkiem tego, że wsie należące do Piotra Kierdejowicza (Plichów, Hodów i Winniki), który przed 1437 rokiem zapewne zmarł bezpotomnie, znalazły się w rękach jego braci: Zygmunta z Chocenia (Plichów i połowa Hodowa), Dymitra ze Szpikłosów (połowa Hodowa) oraz (Jana) Hryćka z Pomorzan, kasztelana lwowskiego (Winniki) ${ }^{83}$. W 1437 roku sąd ziemski lwowski poświadczył ugodę zawartą wobec sześciu arbitrów między braćmi Zygmuntem a Dymitrem, w której podzielili między siebie Hodów. Zygmunt otrzymał południowo-zachodnią połowę wsi, której granicę wyznaczał potok Szwaryca płynący przez jej środek, poczynając od jego źródła (summitas paludinis ${ }^{84}$ ), aż do granicy z Pomorzanami (później była tam wieś Kalne), a Dymitr północno-wschodnią połowę od strony rzeki Strypy, aż do granicy z Pomorzanami ${ }^{85}$. Po śmierci Zygmunta z Chocenia i Wojniłowa, chorążego lwowskiego (1436-1441), jego synowie dokonywali kilkakrotnych podziałów. W 1443 roku Hodów (zapewne połowę pozostałą w rękach Zygmunta po podziale z bratem) dzierżył Michał ${ }^{86}$. W 1447 roku wszyscy synowie Zygmunta: Michał, Mikołaj Starszy, Jan, Jakub i Mikołaj Młodszy, oraz córka Katarzyna podzielili między siebie dobra po ojcu, w tym również te przejęte po Piotrze. Spośród tych ostatnich Michał miał odziedziczyć Plichów, a Mikołaj Starszy Hodów ${ }^{87}$. Jako dziedzic Plichowa Michał wystąpił dwukrotnie w 1448 roku, lecz w tym samym roku z Plichowa pisał się także Mikołaj Starszy ${ }^{88}$. Ze źródeł wynika, że sprawa dotyczyła wydarzeń sprzed 1447 roku, kiedy Mikołaj był jeszcze dziedzicem Plichowa (z jakiegoś wcześniejszego podziału). W 1451 roku, po śmierci Anny z Chocenia, matki młodszych synów Zygmunta: Jakuba i Mikołaja, która trzymała Choceń i Studziankę, wszyscy bracia dokonali powtórnego podziału. Wówczas Michałowi przypadły Hodów i Plichów, Mikołaj Starszy zaś podzielił się z resztą braci pozostałymi dobrami w ziemi halickiej ${ }^{89}$. Jak już wspomniano, Michał Kierdej z Wojniłowa w 1463 roku sprzedał te wsie za 50 grzywien Janowi

${ }^{83}$ ADPom. 3, s. 1-2; AGZ, T. 12, nr 1801; KatBit, nr 63; UrzRus, nr 825; F. KIRYK: Kierdej Jan..., s. 423-424.

${ }^{84}$ Summitas znaczy w tym przypadku tyle co ortus — 'początek, źródło', np. „ad ortum seu summitatem fluminis”, „usque ad summitatem rivuli alias na werzchowine strugi”, zob. Kodeks dyplomatyczny Litwy. Wyd. E. RACZYŃsKi. Wrocław 1845, s. 287, r. 1422, nr 8; Volumina legum. T. 1. Wyd. J. Ohryzko. Petersburg 1859, s. 60, r. 1436; KTyn, nr 263 r. 1475; cyt. za: Kartoteka Słownika Łaciny Średniowiecznej Instytutu Języka Polskiego PAN w Krakowie; pol. „wierzchowina” - 'górny, początkowy bieg rzeki lub strumienia' (Słownik staropolski. T. 10, z. 3. Wrocław 1990, s. 192-193).

${ }^{85}$ ADPom. 3, s. $1-2=4$, s. $1-2=4$, s. 5 .

${ }^{86}$ AGZ, T. 14, nr 673.

${ }^{87}$ AGZ, T. 12, nr 1801.

88 AGZ, T. 14, nr 2011-2012, 2142, 2153.

89 Rewizja Listów 1564, k. 278v-279v. 
Śwince z Pomorzan ${ }^{90}$. Wydaje się, że Świnka był w posiadaniu jedynie części Plichowa, gdyż przed 1492 rokiem Mikołaj Kierdej z Plichowa, syn Michała Wojniłowskiego, zastawił Plichów i połowę Hodowa leżącą od strony Koniuchów Zygmuntowi z Pomorzan, staroście trembowelskiemu, synowi Jana Hryćka z Pomorzan, za 400 grzywien $^{91}$. Natomiast w 1493 roku tenże Mikołaj zamienił z Zygmuntem wspomniane dobra za wieś Chilczyce w powiecie lwowskim i dopłatę 100 grzywien $^{92}$. Decyzja ta mogła być spowodowana roszczeniami do dóbr pomorzańskich (w tym do Plichowa) zgłaszanymi przez Sienieńskich z Gołogór w kontekście sporu o spadek po Świnkach, o czym dalej ${ }^{93}$. W ten sposób Kierdejowicze z linii Zygmunta z Chocenia pozbyli się swej części dóbr pomorzańskich.

Dymitr ze Szpikłosów otrzymał w podziale z 1423 roku Szpikłosy, Snowicz i Urmań ${ }^{94}$. O ile dwie pierwsze wsie, położone blisko siebie w północnej części dóbr pomorzańskich, stanowiły zwarty kompleks, o tyle Urmań, leżący w części południowej, był od nich bardziej oddalony. To najdalej wysunięty „cypel” dóbr pomorzańskich, sąsiadujący z Plichowem i Rozhadowem (należącymi do dóbr pomorzańskich), od południa i południowego zachodu z Buszczem, Poruczynem i Dryszczowem Łabętów, a od wschodu z wsią monarszą Koniuchy. Ponadto w rękach Dymitra znajdowała się co najmniej od 1437 roku wzmiankowana wschodnia część Hodowa. W 1445 roku Dymitr zapisał klasztorowi dominikanów lwowskich 12 kop groszy od spustu ze stawu w Urmaniu oraz 4 kopy groszy od spustu ze stawu w Rzemieniowcach w zamian za odprawianie przez nich mszy świętej przy ołtarzu Świętego Krzyża w kościele Bożego Ciała we Lwowie za dusze jego rodziców Hryćka i Klary pochowanych tamże oraz $\mathrm{w}$ intencji jego własnej, żony i dzieci ${ }^{95}$. Jest to też pierwsza wzmianka o Rzemieniowcach, które należały do Dymitra, podobnie jak wspomniany w 1442 roku Czyżów, który został najechany przez Jana Świnkę z Pomorzan ${ }^{96}$. Te ostatnie wsie wraz ze Szpikłosami i Snowi-

90 ADPom. 3, s. 2-3.

91 AGZ, T. 15, nr 2253; A. Boniecki: Herbarz Polski..., s. 45.

92 ADPom. 5, s. 1-3.

93 AGZ, T. 15, nr 2254.

$94 \mathrm{Z}$ akt ziemskich kamienieckich (Центральний Державний Історичний Архів України у Києві, фонд: 3, опис 1 справа 1 [Acta Terrestria Camenecensia], k. 127v) wynika, że Władysław III nadał Dymitrowi Kierdejowi z Pomorzan wieś Wróblowice na Podolu, co potwierdza informacja o przedłożeniu przez jego syna Piotra Szpikłoskiego dokumentu z tym nadaniem na rewizji listów w 1469 r. (BRO, s. 53; Materiaty do repertorium podolskiego. Dokumenty z lat 1430-1447. Oprac. J. Kurtyka. W: J. Kurtyka: Podole w czasach jagiellońskich..., nr 147, s. 498). Określenie Dymitra jako „de Pomorzany” może oznaczać, że posiadał jakieś prawa do Pomorzan, do czego prawdopodobnie odniósł się Zygmunt Kierdej, syn Jana Hryćka, w zeznaniu z 1498 r., nazywając Dymitra swoim dziadem zamiast stryjem (AGZ, T. 15, nr 4560).

${ }_{95}$ AGZ, T. 2, nr 70; ArchDomKr, sygn. Lw. 024 = Lw. 020.

96 AGZ, T. 14, nr 453. 
czem stanowiły zwarty klucz od północy zamykający kompleks pomorzański. Dymitr nie uniknął również waśni z sąsiadami. W 1446 roku wraz z synem Mikołajem procesował się z Janem Łabętą z Żukowa ${ }^{97}$, a o jego konflikcie z Janem Świnką w 1453 roku wspomniano już wcześniej w niniejszym artykule ${ }^{98}$.

Dymitr ze Szpikłosów zmarł zapewne pod koniec 1457 roku lub krótko potem, gdyż brak na jego temat kolejnych wzmianek źródłowych (ostatni raz pojawił się 3 grudnia 1457 roku) ${ }^{99}$. Wówczas najpewniej nie żyli już jego dwaj starsi synowie występujący w źródłach za jego życia: Mikołaj (1446) i Dymitr Kierdej (1448-1455) ${ }^{100}$. Mikołaj prawdopodobnie zmarł bezpotomnie, Dymitr zaś pozostawił syna Marcina, którego opiekunem w 1471 roku był stryj Jan z Urmania ${ }^{101}$. On jednak także jest znany tylko z jednej wzmianki źródłowej. Z córek Dymitra starsza - Katarzyna — była w 1443 roku żoną Jakuba Klusa, z kolei Anna, żona Jana z Czyżykowa, w 1471 roku zeznała, że bracia spłacili ją z dóbr macierzystych ${ }^{102}$. Majątkiem podzielili się dwaj młodsi synowie Dymitra: Piotr i wspomniany Jan. Piotr ze Szpikłosów i Rzemieniowic, podczaszy lwowski (1469-1486) ${ }^{103}$, zachował w swych rękach trzon dziedzictwa: Szpikłosy, Rzemieniowce, Snowicz i Czyżów. Natomiast Jan z Urmania dostał Urmań i połowę Hodowa. Piotr prawdopodobnie pobierał w Rzemieniowcach cło, co czynił bezprawnie, gdyż o to został oskarżony w 1469 roku przez królewskiego instygatora Mikołaja Grzymałę. Zaprzeczył, ale musiał przysiąc, że nie będzie tego czynił ${ }^{104}$. Od 1471 roku Szpikłoski wiódł również

97 Tamże, nr 1700, 1718, 1733.

98 Tamże, nr 2896, 3787, 3789.

99 AGZ, T. 15, nr 193. W dokumencie sądu ziemskiego lwowskiego z 1479 r. (znanym z potwierdzenia przez tenże sąd w 1569 r.) Daszko z Sukmanowa oskarżył Dymitra ze Szpikłosów o liczne rabunki i zajazdy oraz domagał się 200 grzywien zadośćuczynienia. Jednak Dymitr wówczas już dawno nie żył, podobnie jak jego syn o tym imieniu (zm. z pewnością przed 1471 r.). Z treści dokumentu wynika, że dotyczył on jednak starszego z Dymitrów, Daszko zaś pojawił się w źródłach dopiero w $1471 \mathrm{r}$. Z datą 1479 zgadzają się jednak osoby: Guntera z Sieniawy, sędziego lwowskiego, i Jana z Wysokiego, podsędka lwowskiego. Być może dokument rzeczywiście był wystawiony w tym roku, lecz na podstawie wpisu do akt umieszczonego tam znacznie wcześniej, jeszcze za życia Dymitra (AGAD, perg. 7355; AGZ, T. 19, nr 2861; UrzRus, nr 1024, 1096).

100 AGZ, T. 14, nr 1700, 1718, 1733, 1834, 2066, 3334; KatBit, nr 69; A. Boniecki: Herbarz Polski..., s. 45.

101 AGZ, T. 15, nr 1111.

102 AGZ, T. 14, nr 840; T. 15, nr 3586; A. BonIeCKI: Herbarz Polski..., s. 45.

${ }^{103}$ UrzRus, nr 795 - tu autor wyznaczył błędną datę śmierci na 1490 r., opierając się na pracy K. MaleczyńsKiego Urzędnicy grodzcy i ziemscy lwowscy w latach 1352-1783 (Lwów 1938, s. 133), który jednak zaznaczył, że Piotr nie żył w 1490 r., nie zaś, że zmarł w 1490 r., a wysnuł ten wniosek na podstawie badań K. GóRSKIEGo (Ród Odroważów w wiekach średnich. RHer 1926-1927, T. 8, s. 65), który błędnie utożsamił Piotra, podczaszego lwowskiego, z Piotrem Odrowążem ze Sprowy, synem Pawła ze Sprowy.

104 AGZ, T. 6, nr 84. 
spory sąsiedzkie z dziedzicami Gołogór i ich poddanymi, ponieważ Szpikłosy graniczyły bezpośrednio z dobrami gołogórskimi (Żukowem i Zaszkowem) ${ }^{105}$. Wspólnie z bratem Janem Urmańskim prowadzili proces z dominikanami lwowskimi przed sądem konsystorskim arcybiskupów lwowskich ${ }^{106}$. Źródła ukazują nam w latach 1484-1485 tylko szereg zapisek proceduralnych, lecz można przypuszczać, że dominikanie upominali się o egzekucję należności z tytułu zapisu poczynionego przez ich ojca Dymitra na spustach stawów w Rzemieniowcach i Urmaniu.

Piotr ze Szpikłosów zmarł między 1486 rokiem, kiedy po raz ostatni był wzmiankowany jako żyjący, a 1494 rokiem. Wówczas wdowa po nim, Anna Konstancja, która zapewne miała wyznaczoną oprawę na wsi Snowicz, gdyż została nazwana jej tenutariuszką, prowadziła spór ze swym szwagrem Janem z Urmania ${ }^{107}$. W 1497 roku Jan z Bałuczyna wyznaczył swej żonie Katarzynie, która była córką Piotra Szpikłoskiego, 100 grzywien posagu i tyleż wiana na swych dobrach ${ }^{108}$. Dobra po Piotrze odziedziczyły jego dzieci, które jeszcze w 1499 roku rozliczały się ze swym stryjem Janem z Urmania z opieki nad nimi. Wówczas Jakub ze Szpikłosów, syn Piotra, miał otrzymać tytułem tegoż rozliczenia 5 grzywien. W 1506 roku tenże Jakub występował już samodzielnie jako dziedzic Szpikłosów i Rzemieniowców ${ }^{109}$.

Drugą część dziedziny Kierdejów Szpikłoskich — Urmań i połowę Hodowa - odziedziczył po Dymitrze Jan z Urmania, zapewne jego najmłodszy syn. W 1470 roku oprawił on swej żonie Zofii, córce Mikołaja Klusa, 100 grzywien posagu i tyleż wiana na wsi Urmań wraz z dworem i połową wielkiego stawu oraz na całej (a raczej swej połowie) wsi Hodów ${ }^{110}$. W latach 1491-1505 obok Jana z Urmania występował jego syn Bartłomiej (Bartosz) z Urmania ${ }^{111}$. Prawdopodobnie zmarł on młodo i bezpotomnie, gdyż brak następnych wzmianek o dzieciach oraz wnukach Jana i Zofii Urmańskich. W kolejnych latach Urmański był nadal aktywny pod względem gospodarczym. W 1508 roku jeszcze raz wyznaczył swej żonie Zofii 200 grzywien oprawy na całym Urmaniu i połowie Hodowa ${ }^{112}$. Jednak już w 1504 roku jako posesorzy Hodowa i innych wsi położonych na wschód od niego pojawili się Mikołaj i Sebastian Chomętowscy ${ }^{113}$. Mieli oni w swych rękach wschodnią część Hodowa, należącą właśnie do Jana z Urmania, którą zapewne otrzy-

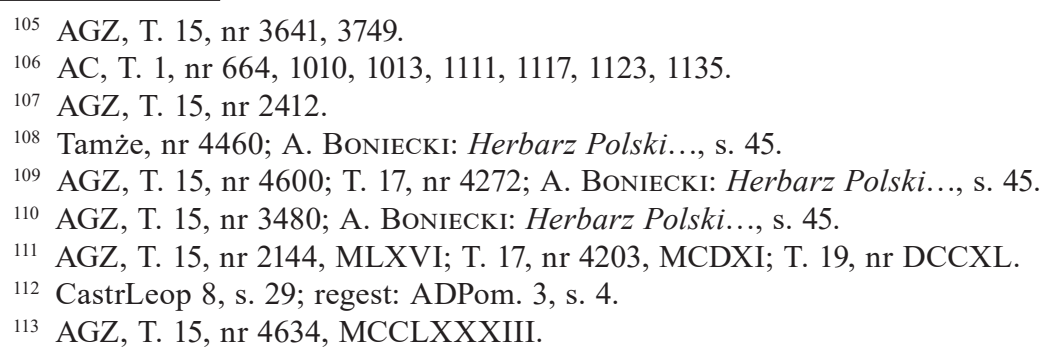


mali od niego w tenucie, choć brakuje na to bezpośredniego dowodu źródłowego ${ }^{114}$. Wówczas na wschód od Hodowa istniały już jego kolonie sięgające brzegu Strypy (Cecowa, Cecówka, Choroborów i Chorościec), gdzie stykały się z osadnictwem postępującym od strony tenuty złoczowskiej. Dlatego w 1504 roku doszło do sporów granicznych i wyznaczenia granicy. Chomętowscy jako nowi posesorzy tych dóbr chcieli zapewne uporządkować sytuację graniczną, tym bardziej że ze wszystkich stron otaczały ich majątek dobra dziedziców Gołogór: od południowego wschodu królewszczyzna złoczowska pozostająca w rękach Sienieńskich ${ }^{115}$, a od północy i zachodu dobra pomorzańskie, które Sienieńscy przejęli w wyniku procesu z Zygmuntem Kierdejem z Pomorzan. W 1511 roku Jan Chomętowski zobowiązał się do odbudowy i wzmocnienia grobli na stawie w Urmaniu oraz do zabezpieczenia jej aż do śmierci Jana z Urmania, po której Chomętowski i jego potomkowie mieli zostać zwolnieni z tego obowiązku. W zamian Jan z Urmania ustąpił Chomętowskiemu z opustoszałej połowy Hodowa wraz z przysiółkami i uroczyskami: Choroborów, Cecowa i połową Chorośćca. Ponadto Chomętowski i jego spadkobiercy mieli dostać prawo pobierania drewna z lasów przynależnych do Urmania na swoje potrzeby oraz wypasu tam świń i prosią ${ }^{116}$. W ten sposób ta część Hodowa ostatecznie przestała należeć do Kierdejów. Niemający żyjących potomków Jan z Urmania w 1517 roku zawarł z Chomętowskim kolejny układ, przekazując mu wraz z żoną Zofią cały swój pozostały majątek. Zmarł prawdopodobnie między 22 czerwca 1520 a 7 maja 1523 roku, kiedy to Jan i Katarzyna Kucharscy pozwali Jana Sienieńskiego o wydzielenie im części Urmania ${ }^{117}$.

114 Okoliczności pojawienia się ich w ziemi lwowskiej są dość zagadkowe. Już w 1457 r. we Lwowie odnotowany jest Pietrzyk z Chomętowa, klient Andrzeja Odrowąża, który na jego polecenie wystąpił wśród asesorów na roczkach grodzkich. Wiele lat później, w 1497 r., zaczął pojawiać się przed sądami lwowskimi Jan Chomętowski, który zajął się reprezentowaniem stron, gdyż był pełnomocnikiem: Jadwigi Romanowskiej, Żydów lwowskich Mojżesza i Judy, Fenny, żony Hryćka Czołowskiego, i jej dzieci, Andrzeja Trzęsitoboła z Berdechowa i Anny Malczyckiej. Prawdopodobnie był skuteczny, gdyż w 1498 r. otrzymał pełnomocnictwo od Jana i Wiktoryna Sienieńskich z Gołogór do prowadzenia ich batalii sądowej z Zygmuntem z Pomorzan o dobra pomorzańskie. Być może znakomite rozpoznanie tych spraw spowodowało, że jego krewni (być może bracia) Mikołaj i Sebastian stali się tenutariuszami połowy Hodowa i jego przysiółków z rąk Urmańskiego (tamże, nr 2521, 2594, 2608-2609, 2621-2622, 2748, 2770, 2940, 3057, 3073, 4553, 4557, 4560, 4578-4579, LVII, CMLIV, MLVIII).

115 Tenuta złoczowska od 1442 r. znajdowała się w zastawie Mikołaja z Gołogór, a w ręce Sienieńskich trafiła wraz z całością dóbr gołogórskich dzięki małżeństwu Andrzeja z Sienna (syna Dobiesława z Oleśnicy i Sienna) z Katarzyną, córką Mikołaja z Gołogór (J. Szyszka: Formowanie i organizacja..., s. 225-228).

116 ADPom. 6, s. 1-2 (regesty: ADPom. 2, s. 1, 5, 9).

117 CastrLeop 10, s. 495-496; 12, s. 206, 680, 742 - 743. Nie wiadomo, czy Chomętowski zrzekł się Urmania na rzecz Sienieńskiego po śmierci Urmańskich, czy w ogóle nie wystąpił o te dobra i Sienieński je przejął. 
8. Do zmagań o spadek po bezpotomnym Mikołaju Śwince z Pomorzan najszybciej przystapili zamożni sąsiedzi — dziedzice Sienna i Gołogór herbu Dębno $^{118}$. Nie mając żadnych tytułów do tych dóbr, już w 1480 roku zamienili z Anną Skarbkową z Szarańczuk swą wieś Leszczków w powiecie lwowskim za połowę miasta i zamku Pomorzany oraz wsi: Bóbrczany, Kalne, Bohutyn, Żabin, Jezierzana, Ryków, Perepelniki, Harbuzów, Jarosławice, Hukałowce i Jworów, wraz z przysiółkami i wsiami opustoszałymi, do których miała prawo po swym zmarłym bratanku Mikołaju Śwince, dopłacając jej 1500 grzywien $^{119}$. Tymczasem majątkiem pomorzańskim po śmierci męża zarządzała Dorota Świnczyna z Oleska, która miała zapisaną oprawę na większości dóbr (Pomorzanach, Rozhadowie, Bóbrczanach, Kalnym i Bohutynie) ${ }^{120}$. Nie ustąpiła z tego majątku, a wkrótce po śmierci Świnki, 5 października 1481 roku była już żoną podkomorzego bełskiego Marcina z Ostrowa ${ }^{121}$. To zapewne uchroniło Dorotę przed sporami z dziedzicami połowy dóbr pomorzańskich, dziećmi tegoż Marcina z Ostrowa i nieznanej z imienia Świnkówny. Spośród nich Andrzej i Michał już 4 maja 1481 roku wystąpili jako dziedzice Pomorzan i Perepelników, 25 sierpnia zaś dołączył do nich Krystyn ${ }^{122}$. Uznawszy prawo macochy do posiadania dóbr oprawnych zapisanych jej przez Świnkę, przejęli w niedziale braterskim tenutę perepelnicką, którą starali się aktywnie zarządzać. Prawdopodobnie jeszcze któryś ze Świnków zapisał na niej jakieś pieniądze Janowi Mściszkowi z Kołtowa, który procesował się z młodymi Ostrowskimi ${ }^{123}$. Po 1484 roku Mściszek zapewne skutecznie wwiązał się w kró-

118 Jan i Wiktoryn z Sienna i Gołogór byli synami Andrzeja z Sienna i Katarzyny z Gołogór, po której odziedziczyli połowę majątku, drugą wykupując od swej bezdzietnej ciotki Elżbiety z Gołogór (F. KIRYK: Sienieński Andrzej z Sienna i Rymanowa. W: PSB, T. 37, s. 172; TenżE: Sienieński Jan z Sienna i Gołogór h. Dębno. W: PSB, T. 37, s. 181; TenżE: Sienieński Wiktoryn z Sienna i Gołogór h. Dębno. W: PSB, T. 37, s. 192; J. Szyszka: Formowanie i organizacja..., s. 225-230).

${ }^{119}$ AGAD, perg. 7361. Uzyskując od niej prawa do przysługującej jej połowy dóbr, nie przystąpili na razie do dalszych działań. Prawami do ich drugiej połowy dysponowała nieznana z imienia siostra Mikołaja Świnki, żona Marcina z Ostrowa, a po jej śmierci (przed 1481 r.) prawami tymi podzieliły się jej dzieci.

${ }^{120}$ AGAD, perg. 7357; AGZ, T. 15, nr 1788; AC, T. 1, nr 1008.

121 AGZ, T. 15, nr 4082. Marcin z Ostrowa w momencie ślubu z Dorotą również był wdowcem, gdyż jego pierwszą żoną i matką wszystkich dzieci była wspomniana wcześniej córka Jana Świnki a siostra Mikołaja (Urzędnicy betscy i chetmscy..., nr 175 - autorzy podali błędnie, że zmarł przed 5 października $1481 \mathrm{r}$, podczas gdy żył jeszcze przynajmniej na początku 1483 r. (AGZ, T. 15, nr 4123), a zmarł przed 15 października 1484 r. (AC, T. 1, nr 935). Błąd mógł wynikać z faktu wystąpienia jego synów jako dziedziców dóbr w niedziale braterskim, lecz dziedziczyli oni wówczas tylko dobra macierzyste).

122 AGZ, T. 15, nr 4069, 4080.

${ }_{123}$ Tamże, nr 1675-1678, 1688-1691, 1700-1702, 1726, 1733, 4069, 4080, 4088, 4089, 4107, 4163-4172, 4205-4206, 4224-4225. 
lewszczyznę perepelnicką z racji swojego długu, gdyż w 1489 roku to on był w jej posiadaniu ${ }^{124}$.

Dorota Świnczyna przed 15 października 1484 roku powtórnie owdowia$\mathfrak{l a}^{125}$. Od śmierci Mikołaja Świnki w źródłach występowała jako dziedziczka bądź tenutariuszka Pomorzan. Od początku też pozostawała w konflikcie z roszczącymi sobie prawa do dóbr pomorzańskich dziedzicami Gołogór ${ }^{126}$. W 1483 roku wiodła spór z Piotrem ze Szpikłosów, krewniakiem zmarłego męża' ${ }^{127}$. W 1484 roku zastawiła za 60 florenów Iwaszkowi Bałabanowi ze Stratyna wójtostwo w Pomorzanach z czterema małymi sadzawkami i trzema kmieciami oraz za 50 florenów wołoską połowę Rozhadowa ${ }^{128}$. Około 1490 roku po raz trzeci wyszła za mąż, poślubiając starostę trembowelskiego Zygmunta Kierdeja, syna Jana Hryćka, który podobnie jak ojciec regularnie pisał się $\mathrm{z}$ Pomorzan ${ }^{129}$. Zapewne ten fakt miał przywrócić $\mathrm{w}$ dobrach pomorzańskich władztwo Kierdejów i wyjaśnić przyszłość majątku. W 1492 roku obydwoje małżonkowie odgraniczyli swe wsie Rozhadów i Plichów (zapewne tę część, którą wykupił Jan Świnka) od dóbr Koniuchy Jana i Falisława ${ }^{130}$. Zygmunt zarządzał dobrami pomorzańskimi wraz z żoną. W 1494 roku zastawił jakiejś Zofii Bóbrczany za 60 grzywien oraz 4 łany osiadłe na przedmieściu Pomorzan za 20 grzywien, a także zobowiązał się oddać Piotrowi Krzywieckiemu z Brzuchowic dług 80 grzywien pod rygorem wwiązania w Rozhadów z połową sadzawki131. Następnie Zygmunt zastawił Dobiesławowi Karasiowi z Oblenic za 80 grzywien połowę Rozhadowa alias Plichowa aż do grobli, którą trzymał wcześniej Stanisław Halka (być może chodzi tu o wspomnianą połowę Plichowa przyległą do Rozhadowa tak, że stała się jej częścią); jeśli nie oddałby tych pieniędzy w terminie, wwiązałby go w drugą połowę Rozhadowa z połową sadzawki i młyna. Zygmunt jednak nie dopuścił Dobiesława do wwiązania w tę wieś, przez co ten dochodził swoich praw jeszcze w 1496 roku, nie mogąc uzyskać zadośćuczynienia. W 1497 roku udało się woźnemu zająć w Pomorzanach jednego woła Zygmunta, lecz nie pokrył on oczywiście kosztów przezysków należnych Dobiesławowi Karasiowi ${ }^{132}$.

124 Tamże, nr 2012.

125 AC, T. 1, nr 935.

126 AGZ, T. 15, nr 4079, 4082, 4123, 4182.

127 Tamże, nr 4133.

128 Tamże, nr 2012, 2022-2023.

1298 stycznia 1490 r. Dorota sama procesowała się z Janem z Koniuch, 11 czerwca 1491 r. zaś wystąpiła przeciw niemu wspólnie z mężem Zygmuntem, który z kolei już 5 marca $1490 \mathrm{r}$. nazwany został tenutariuszem swojej części Pomorzan, podobnie jak Dorota, co pozwala określić czas ślubu na początek 1490 r. (tamże, nr 4300, 4354, 4380 -4383; T. 19, nr DCCXL).

130 AGZ, T. 19, nr 2964, DCCXL.

131 AGZ, T. 15, nr 2398-2399, 2401. Luka w zapisce uniemożliwia prawidłowe zidentyfikowanie tej Zofii.

132 Tamże, nr 2436, 2489, 2497, 2527, 2529. 
Małżeństwo z Zygmuntem Kierdejem poważnie zagroziło planom przejęcia dóbr pomorzańskich po śmierci Doroty przez Sienieńskich z Gołogór. Już 5 marca 1490 roku, tytułując się dziedzicami Gołogór i Pomorzan (de Gologori et Pomorzany heredes), a Zygmunta Kierdeja nazywając tenutariuszem swojej części Pomorzan (tenutarium de sorte ipsius Pomorzany), pozwali go o wyłowienie ryb z ich sadzawki w Pomorzanach, co jego włodarz Maciej i poddani uczynili z jego rozkazu ${ }^{133}$. W 1492 roku Dorota w sprawie z Sienieńskimi o Kalne i Bóbrczany na podstawie okazanego dokumentu wiennego uzyskała mandat królewski nakazujący staroście ruskiemu Spytkowi z Jarosławia pozostawienie jej w posiadaniu tych wsi zajętych przez Sienieńskiego, który w 1493 roku przedłożyła przed sądem starosty. Jarosławski wziął pod uwagę trzy dokumenty: minutę wyjętą z akt ziemskich w sprawie Kalnego, zapis 100 grzywien i 20 kop groszy na Bóbrczanach (obydwa przedłożone przez Andrzeja z Sienna w imieniu syna Jana Gołogórskiego) oraz dokument posagowo-wienny przedłożony w imieniu Doroty przez jej brata Pawła Oleskiego, podkomorzego lwowskiego. Przyjrzawszy się im, starosta przysądził Kalne Dorocie, uznając pierwszeństwo jej dokumentu i dając jej woźnego do wwiązania. Natomiast Bóbrczany pozostawił w rękach Jana Gołogórskiego, uznawszy przedstawione przez niego zapisy, lecz jednocześnie przyznał Dorocie prawo wykupu tej wsi za wymienione kwoty ${ }^{134}$. W 1494 roku Sienieńscy próbowali podważyć przed sądem ziemskim lwowskim decyzję starosty o wwiązaniu Świnczyny do wsi Kalne, a właściwie oddalenie przez starostę ich sprzeciwu, który uczynił to ze względu na błąd w dacie. Jednak sąd ziemski, nie mogąc rozstrzygnąc tej sprawy, dopiero 16 sierpnia 1497 roku wysłał zapytanie do starosty ruskiego Mikołaja z Tęczyna o to, czy powinien oddalić pozew Sienieńskich, czy uznać ich roszczenia ${ }^{135}$. Ten zdążył jeszcze przed wyjazdem na wyprawę mołdawską wystawić dokumenty z odpowiedzią i odesłać je do sądu ziemskiego, który 30 marca 1498 roku przysądził Kalne Janowi z Sienna i Gołogór ${ }^{136}$. W 1492 roku

${ }_{133}$ Tamże, nr 4354, 4380—4383, 4387. Przed 1480 r. Mikołaj Świnka zapisał Kalne swej ciotce Annie Skarbkowej w dożywocie. Po jego śmierci Anna, zamieniwszy z dopłatą swe prawa do połowy dóbr pomorzańskich za wieś Leszczków, wwiązała Sienieńskich w Kalne, które miała już w swych rękach. Od tego czasu to oni dzierżyli tę wieś (ADPom. 1, s. $1-2)$.

${ }^{134}$ AGZ, T. 9, nr 102; T. 15, nr 2318-2319, 4418; UrzRus, nr 988.

135 ADPom. 1, s. 1-2.

${ }^{136}$ AGZ, T. 15, nr 4561; AGAD, perg. 7402. Zapiska nr 4561 umieszczona została przez wydawców AGZ pod roczkiem z 13 kwietnia 1498 r. (nr MCCLXIX), lecz odpowiada tej dacie tylko pięć pierwszych zapisek (nr 4533-4537) ze s. 304 oryginału. Potem następuje przerwa zaznaczona przez wydawców kropkowaną linią, a kolejne zapiski (nr 4538 - 4586) pochodzą już ze s. 581-599 oryginału i z pewnością nie należą do tego roczku (nie zgadza się choćby skład asesorów wymienionych w zapiskach nr 4556, 4574), a ze względu na stan oryginalnej księgi (znaczne zniszczenie i przemieszanie składek) trudno ustalić datę roczku. Wiemy tylko, że odbył się po 26 marca (nr 4569). Jednak w 1569 r. sąd ziemski lwowski zapewne na wniosek Sienieńskich wystawił dokumenty z protestacjami stron zgodnymi z treścią zapisek $\mathrm{nr} 4561$, 
Zygmunt Kierdej wziął w zastaw od Mikołaja Kierdeja za 400 grzywien jego część Plichowa i Hodowa (o czym już wspomniano), lecz Jan z Sienna i Gołogór natychmiast oprotestował tę transakcję, twierdząc, że te wsie należą do połowy dóbr pomorzańskich, które kupił od Andrzeja, Krystyna, Michała i ich sióstr z Ostrowa ${ }^{137}$. Obydwie strony sporu o dobra pomorzańskie wyrządzały sobie nawzajem liczne szkody, czego efektem były potem pozwy. W 1498 roku Zygmunt oskarżył Sienieńskich o to, że po śmierci Pawła z Oleska (po 23 czerwca 1494 roku), podkomorzego lwowskiego, zabrali od niego ze Złoczowa dokumenty i przywileje w sprawie dóbr pomorzańskich będące własnością Zygmunta, oraz że Jan Brudzyński, faktor Sienieńskich, wyjechawszy z Gołogór, uprowadził osiem wołów Zygmunta. Natomiast Sienieńscy obwiniali Zygmunta o to, że jego pięciu dworzan, wyjechawszy wraz z pięcioma poddanymi z jego zamku w Pomorzanach, przybyło do stawu pomorzańskiego należącego do Sienieńskich i wyłowiło z niego sieciami ryby różnych gatunków wartości 29 grzywien ${ }^{138}$. Być może kosztochłonne spory i ciągłe szkody spowodowały, że Zygmunt musiał zadłużać dobra. W latach 1497-1498 był winien Kleofie z Chodorostawu 200 grzywien, pod rygorem wwiązania w Rozhadów, z sadzawką ze spustem, młynem z wymłóconym zbożem, oraz w ośmiu kmieci na przedmieściu Pomorzan pod zamkiem ${ }^{139}$. Dopiero 3 marca 1498 roku Zygmunt uwolnił Rozhadów od zastawu u Jana Sieniawskiego, któremu oddał 300 grzywien ${ }^{140}$.

Dnia 1 lutego 1494 roku Andrzej i Krystyn z Ostrowa, synowie Marcina i jego pierwszej żony (córki Jana Świnki), zamienili z Janem i Wiktorynem z Sienna i Gołogór połowę: miasta Pomorzany, jego zamku i przedmieść oraz wsi: Bóbrczan, Rozhadowa, Podhrebców, Plichowa, Kalnego, Bohutyna, Żabina, Jeziernej, Rykowa, Perepelników i Iworowa wraz z przysiółkami, które to dobra odziedziczyli po zmarłym wuju Mikołaju Śwince, w zamian za Ściankę w powiecie lwowskim z dodaniem 2000 florenów. Ponadto Sienieńscy mieli wykupić za własne pieniądze wszystkie zastawy w tych do-

4573, 4574 (AGAD, perg. 7402, 7404), w których jako datę wpisania ich do księgi podano 30 marca 1498 r. Nie ma powodu, by ją podważać, gdyż wówczas księgi były jeszcze w dobrym stanie.

Wkrótce potem Sienieńscy oddali Kalne w tenutę Janowi Chomętowskiemu, co potwierdzają źródła w latach 1500-1511 (AGZ, T. 19, nr 2608; ADPom. 6, s. 1-2). Możliwe, że była to nagroda za jego wkład w zwycięskie zakończenie sporu z Kierdejem o dobra pomorzańskie.

137 AGZ, T. 15, nr 2253-2254.

138 Tamże, nr 4558 (być może pozew dotyczył tego samego zdarzenia, o które pozwali Zygmunta już w 1490 r., z tą różnicą, że wówczas oskarżyli go o nakazanie swym poddanym tego procederu, ale nie określili wartości wyłowionych ryb — zob. tamże, nr 4387, 4560, 4562, 4564; UrzRus, nr 988; W. Bukowski: Sienieński (Oleski) Jan z Sienna i Oleska h. Dębno. W: PSB, T. 37, s. 181).

139 AGZ, T. 15, nr 2565, 2642-2643, 2645.

140 Tamże, nr 2641. 
brach oraz spłacić Dorotę z Oleska z zapisanej na nich oprawy. Andrzej i Krystyn jednocześnie przekazali Janowi z Sienna opiekę nad swą nieletnią siostrą Małgorzatą. Natomiast Marcin z Wojsławic, syn Barbary z Ostrowa oraz siostrzeniec Andrzeja i Krystyna, w imieniu chorej matki skwitował Sienieńskich z zapłacenia jej za te dobra, które odziedziczyła po swej matce i wuju Mikołaju Śwince, oraz wraz ze swymi wujami poręczył Sienieńskim, że po wyzdrowieniu Barbara stawi się przed sądem i potwierdzi kwitację ${ }^{141}$.

Po tym fakcie sytuacja procesowa Zygmunta stawała się coraz mniej korzystna. Sienieńscy, zdobywając kolejne cesje od spadkobierców Świnków, skompletowali wszystkie tytuły do dóbr pomorzańskich w swoich rękach. Natomiast Zygmunt swe roszczenia opierał z jednej strony na prawach żony do oprawy po zmarłym pierwszym mężu Mikołaju Śwince, a z drugiej — na niejasnych własnych koncepcjach, które starał się artykułować w pozwach, twierdząc, że jest naturalnym właścicielem tych dóbr po dziadku, ojcu i stryju Mikołaju Śwince, którzy byli dziedzicami Pomorzan, a więc sam się dziedzicem nazywał i pisał (,,Sigismundus heres de Pomorzany solus se heredem cognominat et scribit") ${ }^{142}$. W dalszym toku tej batalii sądowej Zygmuntowi udało się uzyskać dokument królewski podważający bezstronność sędziego i podsędka ziemskich lwowskich w jego sprawie z Janem Sienieńskim i przydzielający im do tej sprawy asesorów: Zbigniewa z Tęczyna, podkomorzego krakowskiego i starostę lwowskiego, Jana z Oleska, kasztelana małogoskiego (szwagra Zygmunta), oraz Pawła Kolę z Dalejowa, kasztelana halickiego. Przedkładając ten dokument przed sądem ziemskim lwowskim 30 marca 1498 roku, Zygmunt zapewne był przekonany, że uda mu się zablokować wydanie wyroku i przeciągnąć sprawę. Jednak Jan Chomętowski, pełnomocnik Sienieńskich, wygłosił wówczas ekspresyjną mowę, w której podważył królewski dokument od strony formalnej, twierdząc, że dotyczy on sprawy Zygmunta z Janem Sienieńskim, a sprawa niniejsza o dobra pomorzańskie prowadzona jest między Zygmuntem a Janem i Wiktorynem Sienieńskimi. Ponadto oskarżył Zygmunta o celowe przedłużanie procesu, gdyż nie przyprowadził on na posiedzenie wyznaczonych przez króla asesorów, żeby móc wnioskować o kolejny termin sprawy i nie dopuścić do ogłoszenia wyroku. Na koniec Chomętowski stwierdził, że

${ }^{141}$ Tamże, nr 2380 -2382. Transakcja ta miała miejsce ok. 2 lata wcześniej, gdyż 13 listopada 1492 r. Jan Gołogórski powołał się na nią przy okazji sporu o Plichów i Hodów (tamże, nr 2254).

${ }^{142}$ Tamże, nr 4560. Zapewne nastąpiła tu pomyłka pisarska, gdyż ojcem Zygmunta był Grzegorz (Hryćko), nie Jerzy, co jest możliwe z uwagi na zbliżone brzmienie tych imion w łacinie. Dziadem Zygmunta był zaś Hryćko, nie Dymitr. Być może Zygmuntowi chodziło o stryja Dymitra ze Szpikłosów, co pisarz błędnie zrozumiał. Pomyłki te przedostały się niestety do literatury i przyjęto je bezkrytycznie (A. Boniecki: Herbarz Polski..., s. 43; J. PAJEWSKI: Szlachcic polski dyplomata tureckim (Jan Kierdej Said-bej). Mies. Her. 1935, T. 14, s. 54). 
to termin zawity, a według prawa ziemskiego i prawa Królestwa monarcha nie powinien ingerować $\mathrm{w}$ przebieg procesu przed sądem ziemskim w terminie zawitym, ponieważ to uniemożliwiałoby zakończenie jakiejkolwiek sprawy, i nie może również tego terminu oddalać. Mowa ta wywołała poruszenie zgromadzonej szlachty, która gromko poparła argumenty przytoczone przez Chomętowskiego, aby nie sądzono tak, ponieważ to jest ze szkodą dla prawa ziemskiego. Sędzia Stanisław Jaryczowski z Knihynic i podsędek Feliks z Bałuczyna, ziemscy lwowscy, nie uwzględniwszy mandatu królewskiego, przysądzili Sienieńskim połowę dóbr pomorzańskich uzyskanych przez nich tytułem zamiany z Anną Skarbkową (ponieważ ich dotyczył pozew) ${ }^{143}$. Sienieńscy pozwali następnie Zygmunta o przezyski za bezprawne użytkowanie ich dóbr, szacując je na 30 grzywien bez wiardunku rocznie. Zygmunt starał się jeszcze bronić, pozywając Stanisława z Knihynic, sędziego ziemskiego lwowskiego, przed sąd króla za nieuwzględnienie mandatu królewskiego, a kiedy po protestacji sędziego i podsędka ten pozew okazał się wadliwy, pozwał go po raz drugi. Kierdej złożył też kilka pozwów przeciw Sienieńskim, lecz wszystkie one zostały oddalone $\mathrm{z}$ powodu niestawienia się Zygmunta (być może wtedy już nie żył $)^{144}$.

Dnia 22 kwietnia 1498 roku starosta lwowski Mikołaj Kreza z Bobolic ustanowił zakład 500 grzywien między Janem i Wiktorynem z Gołogór a Dorotą i Zygmuntem Kierdejowiczem ${ }^{145}$. 7 maja woźny sądowy zeznał, że dokonał wwiązania Sienieńskich z Gołogór w połowę miasta i zamku Pomorzany z połową Rozhadowa, Bohutyna i innych przynależnych do tych dóbr, a osobno wwiązał Jana $\mathrm{w}$ wieś Kalne ${ }^{146}$. W tym samym czasie nastąpiły tragiczne wydarzenia, które przypieczętowały klęskę Kierdejów. Wojska tureckie dowodzone przez baszę Silistrii Balu beja Malkocz oglu w rewanżu za wyprawę bukowińską Jana Olbrachta z 1497 roku wkroczyły na Podole i, podążając na

143 AGZ, T. 15, nr 4553.

144 Tamże, nr 4554-4567; AGAD, perg. 7404. O procesie wzmiankował jedynie A. ProCHaska: Poturczeniec dyplomata. „Przewodnik Naukowy i Literacki” 1920, T. 48, z. 6, s. 531, 541. Wprowadził on wiele szczegółów wydarzeń z 1498 r. dzięki przedstawieniu zeznań świadków procesu z 1532 r., lecz oprócz tego bezkrytycznie przyjął bałamutne genealogiczne wymysły B. ZAmorskiego (Kronika Pomorzańska..., s. 14, 23-25, 27), uznając istnienie Zygmunta Oleśnickiego, starosty trembowelskiego (sic!), rzekomo drugiego męża Anny Skarbkowej, a brata Jana z Sienna, który po śmierci tegoż rzekomego Zygmunta Oleśnickiego w wyprawie wołoskiej w 1497 r. miał przejąć Pomorzany. Prochaska we wnioskach (Poturczeniec dyplomata..., s. 541) jeszcze bardziej mylnie uznał, że Zygmunt Kierdej miał jedynie nikłe prawa do Pomorzan po dziadku swej drugiej żony (dziadkiem Doroty z Sienna był Dobiesław z Oleśnicy, wojewoda sandomierski!), z której „nie miał potomstwa, podczas, gdy Sienieński [...] miał męskie potomstwo ze Świnkówny" (sic!) — teza ta jest prawdopodobnie twórczym rozwinięciem wymysłów Zamorskiego.

145 AGZ, T. 15, nr 2665.

146 Tamże, nr 2669-2670. 
północny zachód przez ziemię halicką, 10 maja zdobyły Rohatyn ${ }^{147}$. Zygmunt przebywał $\mathrm{w}$ tym czasie $\mathrm{w}$ Trembowli, skąd dwa tygodnie przed tureckim najazdem wyjechał do Pomorzan, gdzie tydzień później przybyła jego żona Dorota $\mathrm{z}$ synem Janem ${ }^{148}$. W części literatury zawarto bezpodstawne twierdzenia, że tam zastały ich wojska tureckie, które obległy i zdobyły zamek pomorzański ${ }^{149}$. Jednak jak wynika z zeznań świadków z procesu z 1532 roku $^{150}$, przytoczonych już przez Antoniego Prochaskę, Zygmunt zdecydował się opuścić Pomorzany, ponieważ „nie pokładał zaufania w zamku Pomorzany” (,non confidens in fortalicio"), i udał się z rodziną do Dunajowa, gdzie dwa tygodnie później dotarły wojska tureckie oraz rozegrały się tragiczne wypadki, w których Zygmunt zginął w trakcie obrony, zaś jego dziewięcioletni syn Jan dostał się do niewoli. Tylko Dorocie udało się zbiec ${ }^{151}$. Wynika z tego, że Zygmunt przybył do Pomorzan ok. 16-17 kwietnia, Dorota z Janem ok. 24-25 kwietnia, a opuścili Pomorzany na początku maja. Tydzień później woźny zeznał we Lwowie, że dokonał wwiązania Sienieńskich w Pomorzany. Czyżby Zygmunt wyjechał z Pomorzan, ponieważ oddał je w ręce Sienieńskich? Może w taki

147 Maciej z Miechowa: Chronica Polonorum. [Lectiones variantes primae editionis (anni 1519)]. W: Scriptores rerum Polonicarum. T. 2. Kraków 1874, s. 262; J. S̨̨KowsKi: Collectanea $z$ dziejów tureckich. T. 1. Warszawa 1824, s. 77 (relacja Saad ad Dina); O GóRKA: Nieznany żywot Bajezida II źródtem dla wyprawy czarnomorskiej i najazdów Turków za Jana Olbrachta. Lwów 1938, s. 40-41; T. Korzon: Dzieje wojen i wojskowości w Polsce. T. 1. Wyd. II. Lwów-Warszawa-Kraków 1923, s. 230; F. PAPÉE: Jan Olbracht. Kraków 1936, s. 160; Z. SPIERALSKi: Po klęsce bukowińskiej 1497 roku. Pierwsze najazdy Turków na Polskę. „Studia i Materiały do Historii Wojskowości” 1963, T. 9, Cz. 1, s. 49-50; L. FAC: Poludniowo-wschodni teatr działań wojennych $w$ latach 1497-1509. Działania wojenne i zagrożenia dla Rusi Czerwonej na przełomie XV i XVI wieku (1497-1509). „Rocznik Przemyski” 2007, T. 43, z. 1, s. 62; M. PleWCZYŃski: Wojny Jagiellonów z wschodnimi i południowymi sąsiadami Królestwa Polskiego w XV wieku. Siedlce 2005, s. 154; K. Niemczyк: Mołdawia w polityce dwóch Jagiellonów: króla polskiego Jana Olbrachta i króla Węgier Władysława (do roku 1501). W: Wielowiekowe bogactwo polsko-rumuńskich związków historycznych i kulturowych. Suceava 2014, s. 64.

148 CastrLeop 16, s. 191; A. Prochaska: Poturczeniec dyplomata..., s. 531, 539.

149 Prawdopodobnie błąd ten powstał u J. PAJEwSKiego (Szlachcic polski..., s. 54), który niedokładnie przytoczył informacje A. Prochaski, a za nim powtarzali go kolejni badacze: Z. Spieralski: Po klęsce bukowińskiej..., s. 50 (autor uznał, że wpierw Turcy zdobyli Pomorzany, a potem udali się pod Rohatyn); Z. Abrahamowicz: Kierdej Jan - Said bej. W: PSB, T. 12, s. 424; L. FAC: Poludniowo-wschodni teatr..., s. 62-63 (badacz wymienia oblężenie Pomorzan po zdobyciu Rohatyna); M. PlewCzyŃski: Wojny Jagiellonów..., s. 154 (autor przedstawia tę samą kolejność wydarzeń co Fac, choć cytuje wyłącznie Spieralskiego).

${ }^{150}$ Świadkami byli: nieznany skądinąd Maciej Golański oraz Jan Włoch — czyli Jan Włoch Cebrowski (1486/1487-1533), tenutariusz Żabokruk, Lubszy i Rzepiechowa — szlachcice i starcy, którzy pamiętali te wydarzenia, podobnie jak obecna przy synu Dorota Świnczyna (CastrLeop 16, s. 149, 167, 192; J. SzyszKa: Formowanie i organizacja..., s. 237, 268, 446, 464).

${ }^{151}$ CastrLeop 16, s. 140-141, 191-192; A. Prochaska: Poturczeniec dyplomata..., s. $539-540$. 
sposób zakończyło się około stuletnie władanie dobrami pomorzańskimi rodziny Kierdejów ${ }^{152}$. Zygmunt zginął zapewne 11 lub 12 maja, w czasie zdobycia Dunajowa ${ }^{153}$.

Po śmierci męża i utracie syna Dorota zaczęła starać się o odzyskanie oprawy, głównie z pomocą braci. Dnia 5 stycznia 1499 roku Mikołaj Kreza z Bobolic, starosta przemyski i lwowski, ustanowił 200 grzywien zakładu między Janem i Piotrem Oleskimi a Janem z Sienna i Gołogór w sprawie sporu o dobra pomorzańskie ${ }^{154}$. W 1499 roku Piotr Oleski w imieniu swej siostry oskarżył przed sądem starosty Jana z Sienna i Gołogór o wyzucie jej z oprawy. Jan twierdził, przedstawiając wyciągi z akt ziemskich, że Dorota odstąpiła dobra oprawne mężowi, który potem stracił je wyrokiem sądu na rzecz Jana i Wiktoryna. Piotr natomiast udowodnił, że Zygmunt przywrócił jej oprawę i umorzył zrzeczenie, gdyż Dorota uczyniła to bez rady i woli przyjaciół. Starosta przysądził Dorocie oprawę i dał woźnego do wwiązania się w te dobra. Wówczas Jan i Wiktoryn Sienieńscy zgodzili się spłacić Dorotę z jej oprawy i natychmiast zawarto transakcję, w której skwitowała ich z zapłacenia jej 1200 grzywien z tytułu tej oprawy (czyli 500 grzywien posagu, 500 wiana i 200 darowizny zapisanych jej przez Mikołaja Świnkę) oraz zrzekła się swych praw do tych dóbr i oddała dokument oprawny ${ }^{155}$. Tak zakończył się spór o dobra pomorzańskie, które na kolejne stulecie przejęli Sienieńscy. W połączeniu z sąsiadującymi z nimi od zachodu dobrami gołogórskimi i od wschodu z tenutą złoczowską stanowiły one w ich rękach potężny kompleks majątkowy. Je-

${ }^{152}$ Świadkowie twierdzili, że po śmierci Zygmunta Pomorzanami zarządzał jego stryjeczny brat Mikołaj Kierdej z Zubowa (jeden z potomków Zygmunta z Chocenia, może identyczny z Mikołajem Kierdejem z Plichowa), lecz wiadomo, że całość dóbr przejął już wcześniej Sienieński. Zapewne Mikołaj Kierdej zarządzał tenutą trembowelską pozostałą po Zygmuncie, tym bardziej że Zubów był częścią tej tenuty (CastrLeop 16, s. 192).

Jan Kierdej, syn Zygmunta, wzięty w jasyr turecki, przeżył i został wychowany w tradycji islamskiej przez kogoś wysokiego rangą, gdyż otrzymał solidne janczarskie wykształcenie i trafił do sipahów — oddziałów jazdy, gdzie zwrócił na siebie uwagę wielkiego wezyra Ibrahima Paszy. Said bej został w 1531 r. wysłany z misją dyplomatyczną do Polski. W czasie swego pobytu w Królestwie spotkał się z matką, żyjącą jeszcze Dorotą Świnczyną, i podjął próbę odzyskania Pomorzan wraz z całym majątkiem szacowanym wówczas na 10000 grzywien. W 1532 r. uzyskał mandat królewski, z którym udał się przed sąd starosty lwowskiego mającego rozpatrzyć sprawę o zwrot dóbr z rąk Sienieńskich, lecz bez powodzenia. Wbrew twierdzeniu Prochaski Jan Kierdej nie zrezygnował i w dalszym ciągu toczył procesy z Sienieńskimi przed sądem sejmowym i ziemskim lwowskim w latach 1533-1558. Nic jednak nie udało mu się uzyskać (tamże, s. 140-149, 165, 167, 190-192; TerrPrem 9, k. 893; AGAD, Zbiór Czołowskiego, sygn. 6, s. 1-104; A. Prochaska: Poturczeniec dyplomata..., s. 534-541; J. PAJEwSKi: Szlachcic polski..., s. 54; Z. Aвrahamowicz: Kierdej Jan..., s. 424-425).

153 Turcy zdobyli Rohatyn 10 maja, pod Lwów dotarli zaś 13 maja, zatem Dunajów (27 km od Rohatyna) musieli zdobyć 11, a najpóźniej 12 maja, nim przebyli $62 \mathrm{~km}$, docierając do Lwowa (M. Plewczyński: Wojny Jagiellonów..., s. 154).

154 AGZ, T. 15, nr 2773-2774; W. Bukowski: Sienieński (Oleski) Jan..., s. 180.

155 AGZ, T. 15, nr 2835-2836. 
dynym wyłomem w jednolitym kształcie dóbr okazała się część Hodowa wraz ze swymi przysiółkami rozrzuconymi aż po brzeg Strypy, którą z rąk Urmańskiego przejęli Chomętowscy (zob. ryc. 4) ${ }^{156}$.

9. Jak pokazują dzieje klucza pomorzańskiego w XV wieku, podlegał on w tym czasie licznym podziałom, ale jednocześnie rozszerzał się, najsilniej ekspandując tam, gdzie nie było jeszcze granic linearnych, w kierunkach szerokich stref granicznych będących najczęściej pustkami osadniczymi kolonizowanymi od strony konkretnych osad ${ }^{157}$. Kolonizowano również obszar w obrębie dóbr, zwłaszcza niezajęte jeszcze przez osadnictwo doliny rzek i potoków, ale też stoki i grzbiety wzgórz porośnięte lasami.

Po podziale dóbr pomorzańskich przeprowadzonym w 1423 roku poszczególni właściciele podejmowali stopniowo akcje kolonizacyjne (zob. ryc. 3). Najwcześniej ich efekty widoczne były w dobrach Dymitra ze Szpikłosów, który obok już istniejących wsi klucza szpikłoskiego (Szpikłosy i Snowicz) aktywnie rozwijał sąsiednie osady. Czyżów wspomniany został już w 1442 roku, Rzemieniowce zaś w 1445 roku, kiedy dochody ze spustu stawu w tej wsi Dymitr nadał dominikanom lwowskim ${ }^{158}$. Te wsie leżały na południe od Szpikłosów i Snowicza, czyli bliżej granic z częścią dóbr pomorzańskich należących do Świnków (Bohutyn, Bóbrczany, Żabin). Być może obydwie istniały już wcześniej jako przysiółki lub dworzyska, lecz niewątpliwie ich rozwój wiąże się z działalnością gospodarczą Dymitra. W następnych latach na obszarze dóbr szpikłoskich nie powstały już nowe osady. Klucz nie rozwinął się też bardziej terytorialnie, gdyż osady, leżąc w wąskich dolinach potoków źródłowego odcinka Złotej Lipy Wschodniej, od południa graniczyły z blisko położonymi Sukmanowem i Bohutynem, od zachodu zaś z dobrami gołogórskimi. Sąsiadując z dobrami rycerskimi, gdzie granica strefowa była już w zaniku i zapewne szybko uległa linearyzacji oraz delimitacji (choć nie zachowały się opisy tych granic z XV wieku), klucz szpikłoski nie mógł rozszerzyć się w tym kierunku. $\mathrm{Na}$ północy strefa graniczna była nieco szersza i schodziła w dół południowymi stokami niedostępnego pasma Woroniaków. Być może ta niedostępność uniemożliwiała skutecznie rozwój osadnictwa w tym kierunku. Warto zaznaczyć, że strefa ta do 1432 roku stanowiła również granicę polsko-litewską. Jedynie od wschodu rozciągał się słabo zasiedlony, szeroki obszar pustek osadniczych, ciągnący się grzbietami oddzielającymi doliny dorzecza Złotej Lipy od doliny Strypy i dalej na północny wschód od niej. U źródeł Małej Strypy umiejscowiony był Ryków, z którego w 1453 roku pisał się Bartosz, zapewne

156 Jak już wspomniano, Jan Chomętowski, zapewne w nagrodę za swą służbę jako pełnomocnik procesowy Sienieńskich, ok. 1498-1500 r. otrzymał od nich w tenutę Kalne, a wkrótce potem wraz z braćmi Mikołajem i Sebastianem wszedł w posiadanie części Hodowa wraz ze wspomnianymi przysiółkami (AGZ, T. 19, nr 2608).

157 T. Figlus: Uwagi na temat procesu ksztattowania się granic wsi..., s. 255-256.

158 AGZ, T. 2, nr 70; ArchDomKr, sygn. Lw. 024. 


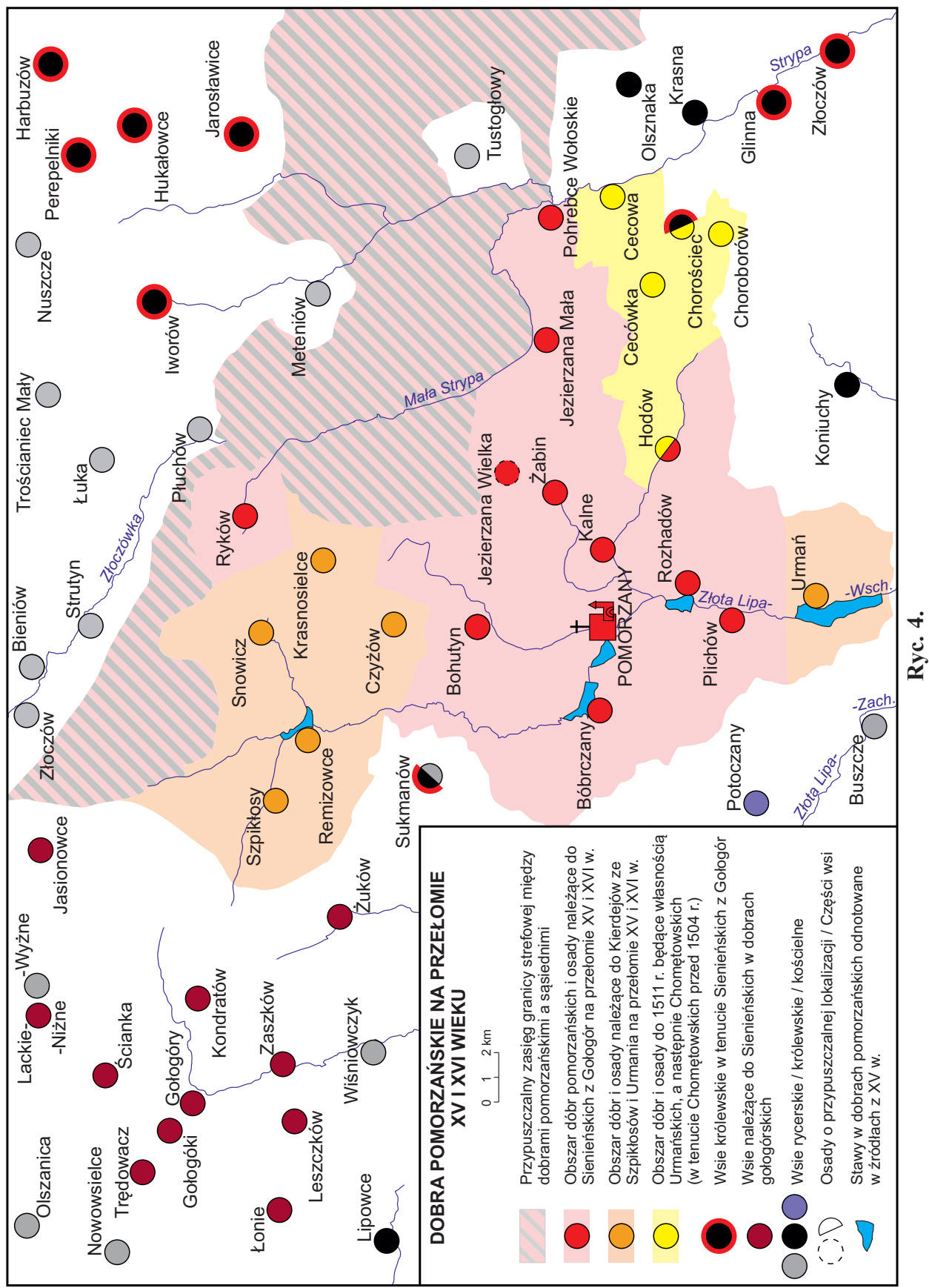


drobny rycerz ${ }^{159}$. Obszar leżący na południe od Rykowa Szpikłoscy próbowali skolonizować, zakładając wieś Krasnosielce, wspomnianą w 1475 roku wraz z innymi ich wsiami, z których mieli zapłacić karę królewską za niedopuszczenie do ciążenia na nich zasądzonego w celu egzekucji podymnego ${ }^{160}$. Także w Urmaniu nie było warunków na zewnętrzną ekspansję osadniczą. Należy pamiętać, że Dymitr i jego następcy posiadali również część Hodowa z podziału z Zygmuntem z Chocenia, o czym dalej.

Świnkowie, którzy mieli najrozleglejszy dział, zaczęli od kolonizacji wewnętrznej, choć nowe osady pojawiły się w źródłach nieco później niż w przypadku Szpikłoskich. Mogły jednak powstać wkrótce po podziale dóbr lub istnieć jeszcze wcześniej w formie przysiółków. W 1464 roku wspomniany został Bohutyn, w 1477 roku Rozhadów, a w 1479 roku Kalne ${ }^{161}$. Ulokowane w dolinach uzupełniały one sieć osadniczą dóbr pomorzańskich usadowioną nad brzegami Złotej Lipy Wschodniej i jej dopływów. Rozhadów ${ }^{162}$ leży nad Złotą Lipą między Pomorzanami a Plichowem, Kalne nad Szwarycą między Hodowem a jej ujściem do Złotej Lipy, a Bohutyn nad jej lewym dopływem Machnówką. Być może powstanie tych wsi, tudzież rozwój dotychczasowych przysiółków, był zasługą Jana Świnki. Z pewnością to on podjął lub kontynuował intensywną ekspansję osadniczą w kierunku leżącej na północny wschód od jego dóbr wspomnianej już szerokiej strefy pustek. Przed 1480 rokiem Świnkowie przejęli z rąk dotychczasowych właścicieli Ryków ${ }^{163}$, co utrudniło Szpikłoskim skorzystanie z pustek osadniczych leżących na wschód od Krasnosielców, i zapewnili sobie przestrzeń do dalszej ekspansji na północny wschód. Równie aktywny rozwój osadnictwa na zewnątrz dóbr następował od strony Żabina. Prawdopodobnie ok. $1 \mathrm{~km}$ na północ od Żabina, w podmokłej, ok. dwudziestometrowej głębokości kotlince zwanej w XIX-XX wieku Oziera ${ }^{164}$ leżała nieistniejąca dziś Jezierzana Wielka. Kotlinka ta otwarta była w kierunku wąwozu prowadzącego do potoku płynącego przez późniejszą Chrabużną, dopływu Małej Strypy. Natomiast Jezierzana Mała położona jest nad zewnętrzną częścią zakola Małej Strypy, którym rzeka zmienia kierunek z południowo-wschodniego na wschodni. Obydwie wsie wzmiankowane były po raz pierwszy w 1472 roku. Jezierzana Wielka mogła powstać dość wcześnie i również był to efekt rozszerzania się osadnictwa oraz ekspansji terytorialnej

159 AGZ, T. 14, nr 2779, 2789.

160 AGZ, T. 15, nr 1385.

161 AGZ, T. 6, nr 45; T. 15, nr 3834; AGAD, perg. 7357.

162 Prawdopodobnie część Plichowa wykupiona przez Jana Świnkę w 1463 r., przyległa do Rozhadowa, stała się jej częścią i w 1494 r. była nazywana Rozhadow alias Plichow. Natomiast drugą połowę Rozhadowa (właściwy Rozhadów) lokowano na prawie wołoskim („medietatem ville sue Roshadow partem Vlachocalem" - ADPom. 3, s. 2-3; AGZ, T. 15, nr 2023, 2436).

163 AGAD, perg. 7361.

164 Third Military Survey (1:25000); Mapa topograficzna WIG, 1:25000..., sekcja P 50, S 40-E. 
w kierunku pustki osadniczej grzbietu dzielącego dorzecza Złotej Lipy i Małej Strypy (odległość między Ozierą a Małą Strypą wynosi zaledwie niecałe $3 \mathrm{~km}$ ), która dotarła w przypadku Jezierzany Małej do brzegu Małej Strypy. Niewątpliwie była to wczesna działalność Jana Świnki, być może równoczesna z rozwojem osadnictwa od strony Bohutyna lub nawet wcześniejsza. Kolejnym etapem tego kierunku rozwoju osadnictwa była lokacja na prawie wołoskim wsi Pohrebce, położonej jeszcze dalej na wschód nad brzegiem Strypy, w miejscu, gdzie łączą się Główna Strypa i Mała Strypa. Wieś ta wzmiankowana została dopiero w 1494 roku, w okresie sporów o dziedzictwo po Świnkach, lecz prawdopodobnie powstała jeszcze w czasach Świnków, gdyż później konflikt Doroty i Zygmunta Kierdeja z Sienieńskim skutecznie ograniczał większe inicjatywy ${ }^{165}$. Ponadto liczne najazdy tatarskie i wołoskie w ostatnich dekadach XV i na początku XVI wieku przyhamowały rozwój osadnictwa w tym rejonie, szczególnie narażonym na to niebezpieczeństwo ze względu na przebiegający dokładnie tamtędy czarny szlak tatarski, prowadzący od strony Załoźców koło Trościańca Wielkiego, przez Główną i Małą Strypę, następnie między Płuchowem i Krasnosielcami i dalej na zachód przez dobra szpikłoskie ${ }^{166}$. Zanim jednak nastąpił ten regres, Jan Świnka aktywnie przeprowadzał akcję kolonizacyjną, tym bardziej że w latach 1442-1456, wszedłszy w posiadanie królewszczyzny perepelnickiej (Perepelniki i Jarosławice) leżącej w dystrykcie oleskim ${ }^{167}$, miał szansę na prowadzenie tej akcji również od północy. Dobra te rozdzielała strefa graniczna (do 1432 roku będąca jednocześnie granicą polsko-litewską), której zasiedlenie z dwóch stron włączyłoby w obręb dóbr Świnki ogromny obszar. Mimo że źródła w latach 1433-1456 wspominały wyłącznie Jarosławice i Perepelniki z młynem oraz użytkami nad rzeką Charbuzową (tak nazwano w dokumencie z 1433 roku źródłowy odcinek Seretu), należy zaliczyć do tego klucza wymieniane w nim od 1480 roku Hukałowce leżące między Jarosławicami a Perepelnikami, Harbuzów (czyli zapewne nienazwane wcześniej użytki nad rzeką Charbuzową) oraz Iworów (Iwaczów) umiejscowiony na północny zachód od Jarosławic, co razem daje dość rozległe terytorium ${ }^{168}$. Zapewne śmierć kolejnych przedstawicieli Świnków, konflikty o spadek oraz okres częstych najazdów spowodowały, że akcji tej wówczas nie dokończono ${ }^{169}$.

${ }^{165}$ AGZ, T. 15, nr 2380. Pohrebce (Pohrebcze alias Voloskie) znalazły się w spisie drugiej połowy dóbr pomorzańskich, którą w 1494 r. Ostrowscy sprzedali Sienieńskim. Nie ma zaś ich w spisie pierwszej połowy tych dóbr sprzedanych w 1480 r. Sienieńskim przez Annę Skarbkową. Być może była lokowana po 1480 r. już przez Dorotę Świnczynę zarządzającą dobrami.

166 G. Le Vasseur de Beauplan: [Delineatio specialis et accurata Ucrainae cum suis palatinatibus]. Gedania 1650.

167 ZDM, Cz. 7, nr 2126; AGZ, T. 14, nr 349, 3539.

168 AGAD, perg. 7361, 7595.

169 Ostrowscy, dziedziczący tenutę perepelnicką po Świnkach, w 1483 r. otrzymali serię pozwów od kmieci Pawła Oleskiego z Sienna, dziedzica dóbr złoczowskich, w których 
Kontynuacją ekspansji osadniczej i własnościowej w kierunku wspomnianych pustek osadniczych położonych na grzbietach dzielących dorzecze Złotej Lipy i Strypy była akcja osadnicza podjęta od strony Hodowa w kierunku wschodnim. Jak już wiemy, Hodów w 1437 roku został podzielony między braci Zygmunta z Chocenia i Dymitra ze Szpikłosów. Dymitr otrzymał wówczas północno-wschodnią część tej wsi (od strony Strypy). Granica osady na tym odcinku nie była jeszcze wtedy wyraźnie określona. W przeciwieństwie do granicy zachodniej z Pomorzanami na wschodzie była to przestrzeń otwarta w kierunku Strypy, czyli obszaru grzbietu między Strypą a Szwarycą, nad którą leży Hodów. Ta granica strefowa oddzielała Hodów od wspomnianych już dóbr złoczowskich rozciągających się również na północ od Złoczowa wzdłuż Strypy. Obszar ten stał się potem obiektem ekspansji osadniczej właścicieli sąsiednich włości ${ }^{170}$. Zapewne jeszcze Jan z Urmania, a może nawet Dymitr ze Szpikłosów wykorzystali peryferyjne położenie tej części Hodowa względem dóbr pomorzańskich i rozpoczęli ekspansję osadniczą we wspomnianym kierunku. Pierwsze osady, wzmiankowane dopiero w 1504 roku, nie powstały jednak w najbliższym sąsiedztwie Hodowa, na zachodnich zboczach lub na grani grzbietu, lecz dalej na wschód, już na wschodnich stokach w dolinkach potoków wpadających do Strypy (Chorościec, Choroborów, potem Cecówka) oraz nad samą Strypą (Cecowa). W tym miejscu zetknęły się $\mathrm{z}$ osadnictwem postępującym $\mathrm{w}$ górę Strypy od strony klucza złoczowskiego (Złoczów i Glinna), gdzie Sienieńscy uzyskali część Chorośćca. W 1504 roku spór graniczny ówczesnych tenutariuszy tych dóbr z Sienieńskimi, jako tenutariuszami Glinnej i Złoczowa oraz dziedzicami dóbr pomorzańskich, doprowadził do wyznaczenia granicy nie tylko z tenutą złoczowską, ale także na północy, gdzie osadnictwo pomorzańskie z okolic Żabina i Jezierzany zaczęło stykać się z osadnictwem od strony Hodowa. Granica przebiegała między Choroborowem, Cecową i częścią Chorośćca Chomętowskich a Glinną i częścią Chorośćca Sienieńskich na południu oraz między Cecową, Cecówką i Hodowem Chomętowskich a Jezierzaną Małą, Kalnem i Rozhadowem Sienieńskich na północy i zacho-

oskarżali oni kmieci z Perepelników o kradzieże i rozboje. Sytuacja taka bez wątpienia mogła mieć podłoże w sporach granicznych i ,ucieraniu” się granicy linearnej między dobrami, gdyż kmiecie Oleskiego pochodzili z: Płuchowa, Łuki, Nuszcza, Trościańca i Manajowa, wsi otaczających szczelnie wieńcem tenutę perepelnicką od zachodu, północy i wschodu (AGZ, T. 15, nr 4163-4172).

${ }^{170}$ Również wyznaczenie początku granicy na źródło potoku (summitas paludinis), które znajdowało się ok. $1 \mathrm{~km}$ na północ od granicy między Hodowem a Koniuchami w XIX w., może świadczyć o istnieniu jeszcze w tym czasie granicy strefowej między tymi osadami ( $\mathrm{Ga}$ licia and Bucovina (1861-1864) - Second Military Survey of the Habsburg Empire. Dostępne w Internecie: https://mapire.eu/en/map/secondsurvey-galicia/ [data dostępu: 19.08.2020] [Mapa topograficzna, tzw. Zdjęcie franciszkowskie, $1: 28800]$ ). 
dzie ${ }^{171}$. Wcześniej była to wspólna przestrzeń ekspansji Kierdejów (Świnków i Urmańskich), lecz na początku XVI wieku Hodów Chomętowskich wraz ze swymi koloniami stał się enklawą w korpusie dóbr Sienieńskich (zob. ryc. 3, 4).

Ostatnim ważnym zjawiskiem $\mathrm{w}$ procesie kształtowania się dóbr pomorzańskich w XV wieku była stopniowa linearyzacja granic ${ }^{172}$. Zachowały się trzy akty wyznaczające lub potwierdzające przebieg granic dóbr pomorzańskich w XV stuleciu (zob. ryc. 3). Najstarszym jest wyznaczenie granicy dzielącej Hodów przy okazji jego podziału między Dymitra ze Szpikłosów a Zygmunta z Chocenia w 1437 roku. Przebiegała ona strumieniem płynącym przez wieś, począwszy od jego źródła, aż do granic pomorzańskich. Dowiadujemy się przy tym o istnieniu wyznaczonej już wcześniej granicy między Hodowem a Pomorzanami ${ }^{173}$. Kolejny akt zakładał potencjalny przebieg granicy, gdyż w 1461 roku Jan Świnka zobowiązał się spłacić Mikołajowi Gołogórskiemu dług pod rygorem przejęcia na własność Bóbrczan, które Mikołaj już trzymał w zastawie. Na tę ewentualność Jan miał oddzielić Bóbrczany od reszty dóbr pomorzańskich. Proponowana granica rozpoczynała się od granicy z dobrami arcybiskupów lwowskich (na wzgórzu leżącym w połowie drogi między Bóbrczanami a Potoczanami) i biegła wzgórzem w kierunku potoku Strzemienna oraz wzdłuż niego, aż do ujścia do Złotej Lipy Wschodniej (zwanej w źródle Koropcem) między Bóbrczanami a Pomorzanami, dalej wzdłuż tej rzeki do grobli na wielkim stawie w Bóbrczanach, przechodząc nią na drugi brzeg, a następnie wzgórzami zwanymi wówczas Szczalby, leżącymi między Złotą Lipą a Machnówką, i dalej między granicami z Sukmanowem oraz Bohutynem, aż do granicy z Czyżowem ${ }^{174}$ (zob. ryc. 4). Kolejną granicę wyznaczono w 1492 roku między Rozhadowem i Plichowem, należącymi do Zygmunta Kierdeja i Doroty Świnczyny, a Koniuchami Jana i Falisława. Rozpoczynała się ona na skrzyżowaniu dróg z Hodowa do Dryszczowa i z Koniuch do Rozhadowa, gdzie zbiegały się granice Hodowa, Koniuchów oraz Pomorzan i Rozhadowa. Granica biegła na południe przez wzgórza grzbietu oddzielającego dolinę Złotej Lipy Wschodniej od potoku Koniuchy, schodząc czasami w dolinki górskich strumieni, pozostawiała po stronie Koniuch gęsty i rozległy las Korsów ${ }^{175}$. Zapewne również wewnętrzne granice dóbr powstałe po podziałach rodzinnych uzyskiwały postać linearną i były szybko delimitowane w terenie. Przykładem jest przebieg granicy między Plichowem a Rozhadowem (czyli dwiema częściami Rozhadowa) wzdłuż grobli sadzawki w Rozhadowie

171 AGZ, T. 15, nr 4634, MCCLXXXIII.

172 T. Figlus: Uwagi na temat procesu kształtowania się granic wsi..., s. 253, 255-256, 271.

${ }^{173}$ ADPom. 3, s. $1-2=4$, s. $1-2=4$, s. 5 .

174 AGZ, T. 6, nr 45.

175 AGZ, T. 19, nr 2964, DCCXL. 
znany z 1490 roku. Mimo że ta część Plichowa należała do Świnków od 1463 roku i została włączona do Rozhadowa, to nadal utrzymywała się odrębność obydwu części wsi ${ }^{176}$.

Oprócz trzech wspomnianych granic oraz granic wewnętrznych szybkiej linearyzacji uległy zapewne granice zewnętrzne dóbr pomorzańskich z sąsiednimi dobrami na południu i zachodzie oraz niektóre granice wewnętrzne (między wydzielonymi częściami) ${ }^{177}$. Ich przebieg (podobnie jak większości granic wewnętrznych) wyznaczyć można na podstawie granic dóbr uchwytnych kartograficznie na początku XIX wieku i uzupełnionych rozgraniczeniami z XVI-XVII stulecia, biorąc również pod uwagę ukształtowanie terenu i warunki krajobrazowe. Najdłużej granice strefowe utrzymały się na północno-wschodniej rubieży dóbr pomorzańskich, gdzie w XV wieku następowała bardzo silna ekspansja osadnicza oraz terytorialna, zahamowana przez najazdy tatarskie i wołoskie pod koniec owego stulecia.

10. Dobra pomorzańskie nadane na początku XV wieku jako zwarty kompleks osadniczy w dolinie Złotej Lipy Wschodniej i jej dopływów uległy z czasem podziałom, a niektóre $\mathrm{z}$ nich okazały się trwałe. W ciągu tegoż stulecia zachodziły też procesy kolonizacji wewnętrznej oraz zagęszczania osadnictwa w obrębie dolin rzecznych, a także ,wychodzenie” na zbocza wzgórz i grzbietów oddzielających owe doliny. Istotnym zjawiskiem uwidaczniającym się zwłaszcza w 2. poł. XV wieku była zewnętrzna ekspansja osadnicza i terytorialna, głównie w kierunkach szerokiej granicy strefowej oraz pustek osadniczych rozciągających się na wschodzie i północy, wzdłuż pogranicza polsko-litewskiego, które od 1432 roku straciło charakter granicy politycznej. Proces ten, zatrzymany w ostatnich latach XV wieku z powodu najazdów tatarskich i wołoskich oraz konfliktu o dobra pomorzańskie, kontynuowany był w XVI wieku (zwłaszcza w 2. poł.) i doprowadził do niemal całkowitej linearyzacji wszystkich granic klucza pomorzańskiego. Dobra te pozostawały w rękach Sienieńskich przez cały XVI wiek, a potem stały się fundamentem dla budowy majątków i latyfundiów magnackich wybitnych rodzin - Cetnerów, a zwłaszcza Sobieskich ${ }^{178}$.

176 ADPom. 3, s. 2-3; AGZ, T. 15, nr 2436.

177 Świadczą o tym liczne spory sąsiedzkie, najczęściej mające swe źródła w naruszaniu granic dóbr, np. konflikty Szpikłoskich z poddanymi Gołogórskich z Żukowa i Zaszkowa (AGZ, T. 15, nr 3641, 3749) czy spory Urmańskich z poddanymi Łabętów z Dryszczowa (tamże, nr 2737).

${ }^{178}$ K. PrzYboś: Wielka wlasność ziemska $w$ powiecie lwowskim $w$ drugiej połowie XVII wieku. W: Język, literatura, kultura, historia Ukrainy. Materiaty z międzynarodowej konferencji naukowej poświęconej dziesięcioleciu krakowskiej ukrainistyki uniwersyteckiej. Red. W. Mokry. Kraków 2003, s. 295; M. KowALSKI: Księstwa Rzeczypospolitej. Państwo magnackie jako region polityczny. Warszawa 2013, s. 211-212 (ryc. 21); M. Usma: Latyfundium Jana Sobieskiego 1652-1696. Opole 2005, s. 35. 


\section{Bibliografia}

\section{Źródla rękopiśmienne}

Archiwum Główne Akt Dawnych w Warszawie: perg. 7258, 7327, 7355, 7357, 7361, 7402, 7404, 7595; Metryka Koronna 55, 71; Tzw. Metryka Litewska, sygn. IV. B. 9 [Księga wpisów przywilejów na dobra w województwie ruskim przedkładanych podczas „rewizji listów” w 1563/1564]; Zbiór Czołowskiego, sygn. 6, 405.

Archiwum Narodowe w Krakowie, Archiwum Dóbr Pomorzany, sygn. 1, 2, 3, 5, 6.

Archiwum Polskiej Prowincji Dominikanów w Krakowie, sygn. Lw. 024 [oryginał pergaminowy].

Biblioteka Książąt Czartoryskich w Krakowie, dok. perg. 170.

Kartoteka Słownika Łaciny Średniowiecznej Instytutu Języka Polskiego PAN w Krakowie.

Центральний Державний Історичний Архів України у Києві, фонд 3, опис 1, справа 1 [Acta Terrestria Camenecensia].

Центральний Державний Історичний Архів України у Львові, фонд 9, опис 1, справа 8, 10, 16 [Acta Castrensia Leopoliensia]; фонд 10, опис 1, справа 155 [Acta Terrestria Leopoliensia]; фонд 14, опис 1, справа 9 [Acta Terrestria Premisliensia].

\section{Źródla drukowane}

Akta grodzkie i ziemskie z czasów Rzeczypospolitej Polskiej z Archiwum tzw. Bernardyńskiego we Lwowie. T. 2, 6, 7, 9, 12, 14, 15, 17, 19. Wyd. O. Pietruski, X. Liske, A. Prochaska. Lwów 1870-1906.

Annales seu cronicae incliti Regni Poloniae opera venerabilis dominin Joannis Dlugiossi canonici Cracoviensis antiquitatum gentis suae observantissimi summa cum diligentia colectae recto veritatis tramite fi deliter custodito. Lib. 10, 12. Ed. C. BACZKowsKI, M. Kowalczyk, J. Mruk, C. Ożóg, C. Pirożyńska, S. Perzanowski, M. Plezia, F. Sikora, D. Turkowska, G. Wyrozumski. Varsoviae 1985-2005.

Bona Regalia Onerata in Terris Russiae etc. Lustratio 1469 r. W: Polska XVI wieku pod wzgledem geograficzno-statystycznym. T. 7. Cz. 1.B: Ziemie ruskie. Ruś Czerwona. Wyd. A. JABŁonowsKi. Warszawa 1902 (Źródła Dziejowe, 18).

Boniecki A.: Herbarz Polski. Cz. 1: Wiadomości historyczno-genealogiczne o rodach szlacheckich. T. 10. Warszawa 1907.

Codex epistolaris saeculi decimi quinti. T. 1-3. Ed. A. SokoŁowski, J. Szujski, A. Lewicki. Kraków 1876-1894.

GóRKa O.: Nieznany żywot Bajezida II źródtem dla wyprawy czarnomorskiej i najazdów Turków za Jana Olbrachta. Lwów 1938.

Inventarium omnium et singulorum privilegiorum, literarum, diplomatum, scriptorum et monumentorum quaecunque in Archivo Regni in Arce Cracoviensi [...]. Ed. E. RyKaCzewsKi. Paris 1862. 
Katalog dokumentów pergaminowych ze zbiorów Tomasza Niewodniczańskiego w Bitburgu. Oprac. J. Tomaszewicz. M. Zdanek. Red. W. Bukowski. Kraków 2004.

Kodeks dyplomatyczny klasztoru tynieckiego. Wyd. W. KętrzyŃsKi, S. SmolKa. Lwów 1875.

Kodeks dyplomatyczny Litwy. Wyd. E. RaCzYŃsKi. Wrocław 1845.

Kodeks dyplomatyczny Matopolski. T. 3-4. Wyd. F. Piekosiński. Kraków 1887-1905.

Księga przychodów i rozchodów miasta (1414-1426). Wyd. A. CzoŁowsKi. Lwów 1905 (Pomniki Dziejowe Lwowa z Archiwum Miasta, T. 3).

Maciej z Miechowa: Chronica Polonorum. [Lectiones variantes primae editionis (anni 1519)]. W: Scriptores rerum Polonicarum. T. 2. Kraków 1874.

Materiaty do repertorium podolskiego. Dokumenty z lat 1430-1447. Oprac. J. KuRTYKA. W: J. Kurtyka: Podole w czasach jagiellońskich. Studia i materiaty. Oprac. M. WilamowsKi. Kraków 2011.

Matricularum Regni Poloniae Summaria, excussis codicibus, qui in Chartophylacio Maximo Varsaviensi assrevantur. Pars 1, 4. Ed. T. WiERzBowski. Varsoviae 1905-1917.

Najstarsza księga miejska (1382-1389). Wyd. A. CzoŁowski. Lwów 1892 (Pomniki Dziejowe Lwowa z Archiwum Miasta, T. 1).

Najstarsze akta konsystorza lwowskiego. T. 1: (1482-1489). Wyd. W. RoLNY. Lwów 1927 (Zabytki Dziejowe, T. 2).

Najstarsze dokumenty dla franciszkanów kamienieckich z lat 1400 i 1402. Wyd. J. KURTYKA. W: J. Kurtyka: Podole w czasach jagiellońskich. Studia i materiaty. Oprac. M. WiLAMOWSKi. Kraków 2011.

NiesieCKi K.: Herbarz polski powiększony dodatkami z późniejszych autorów, rękopismów, dowodów urzędowych. Wyd. J.N. BoBrowicz. T. 5. Lipsk 1840.

Repertorium podolskie dokumenty do 1430 roku. Oprac. J. KunTyka. W: J. Kurtyka: Podole w czasach jagiellońskich. Studia i materiały. Oprac. M. Wilamowski. Kraków 2011.

S̨̨коwski J.: Collectanea z dziejów tureckich. T. 1. Warszawa 1824.

Uruski S.: Rodzina. Herbarz szlachty polskiej. T. 6. Warszawa 1909.

Volumina legum. T. 1. Wyd. J. OHRYzKo. Petersburg 1859.

Zbiór dokumentów małopolskich. Cz. 1, 6, 7, 8. Wyd. S. Kuraś, I. SuŁkowsKa-Kuraś. Wrocław 1962-1975.

Матеріали до історії суспільно-політичних і економічних відносин західньої України. Ч. 1 -2. Под. М. Грушевський. „Записки Наукового Товариства імени Шевченка” 1905, Т. $63-64$.

Молдован А.М.: Пять новонайденных украинских грамот кония XIV - начала XV в. В: Лингвістическое Источниковедение и исторя русского яазыка. Москва 2000.

\section{Źródla kartograficzne}

Beauplan G. Le Vasseur de: [Delineatio specialis et accurata Ucrainae cum suis palatinatibus]. Gedania 1650.

Galicia and Bucovina (1861-1864) - Second Military Survey of the Habsburg Empire. Dostępne w Internecie: https://mapire.eu/en/map/secondsurvey-galicia/ [data dostępu: 19.08.2020] [Mapa topograficzna, tzw. Zdjęcie franciszkowskie, $1: 28800$ ]. 
Galicja na józefińskiej mapie topograficznej 1779-1783. Wyd. Z. BudzyŃski. T. 12. Cz. A i B;

T. 13. Cz. A i B. Warszawa 2016-2018.

Habsburg Empire (1869-1887) — Third Military Survey (1:25000). Dostępne w Internecie:

https://mapire.eu/en/map/thirdsurvey25000/ [data dostępu: 19.08.2020].

Mapa topograficzna WIG, $1: 25000$. Warszawa 1934.

\section{Opracowania}

Aвrahamowicz Z.: Kierdej Jan - Said bej. W: Polski stownik biograficzny. T. 12. Wrocław 1966 - 1967.

BIEDRZYCKA A.: Bibliografia pomników kultury dawnych kresów poludniowo-wschodnich Rzeczypospolitej. Kraków 2000.

BudZyŃsKi Z.: Kresy południowo-wschodnie $w$ drugiej połowie XVIII wieku. T. 2: Atlas geograficzno-historyczny. Przemyśl-Rzeszów 2006.

Bukowski W.: Sienieński (Oleski) Jan z Sienna i Oleska h. Dębno. W: Polski stownik biograficzny. T. 37. Warszawa-Kraków 1996-1997.

CHWALEwiK E.: Zbiory polskie. Archiwa, biblioteki, gabinety, galerje, muzea i inne zbiory pamiątek przeszłości w ojczyźnie i na obczyźnie. T. 2. Warszawa-Kraków 1927.

CzwoJdrak B.: Powiazania genealogiczne Hanusza i Jana Mężyka z Dąbrowy herbu Wadwicz z Rogowskimi herbu Działosza i Dlugoszami herbu Wieniawa. W: Społeczeństwo Polski średniowiecznej. Red. S.K. KucZYŃsKI. T. 10. Warszawa 2004.

DworZaCzeK W.: Leliwici Tarnowscy. Z dziejów możnowładztwa polskiego. Wiek XIV—XV. Warszawa 1971.

Ehrlich L.: Starostwa w Halickiem w stosunku do starostwa lwowskiego w wiekach średnich (1390-1501). Lwów 1914 (Studya nad historyą prawa polskiego, 6).

FAC L.: Poludniowo-wschodni teatr działań wojennych w latach 1497-1509. Działania wojenne i zagrożenia dla Rusi Czerwonej na przełomie XV i XVI wieku (1497-1509). „Rocznik Przemyski" 2007, T. 43, z. 1.

Fastnacht A.: Stownik historyczno-geograficzny ziemi sanockiej w średniowieczu. Cz. 3. Do druku przygotowali A. Fastnacht-Stupnicka, A. Gąsiorowski. Kraków 2002.

Figlus T.: Uwagi na temat procesu ksztaltowania się granic wsi w Polsce do końca XVIII wieku w kontekście morfogenetycznym. „Studia z Geografii Politycznej i Historycznej” 2015, T. 4.

Górski K.: Jan ze Szczekocin. W: Polski stownik biograficzny. T. 10. Wrocław 1962-1964.

GóRsKi K.: Ród Odrowązów w wiekach średnich. „Rocznik Polskiego Towarzystwa Heraldycznego" 1926-1927, T. 8.

HaIsIG M.: Herb Kierdeja w świetle zabytków sfragistyki średniowiecznej. „Miesięcznik Heraldyczny" 1936, T. 15, nr 7-8.

Halecki O.: Dzieje Unii Jagiellońskiej. T. 1. Kraków 1919.

HŁadYŁowiCZ K.J.: Zmiany krajobrazu w ziemi lwowskiej od połowy XV do poczatku XX wieku. W: Studia z historii społecznej i gospodarczej poświęcone Profesorowi dr Franciszkowi Bujakowi. Lwów 1931.

KirYk F.: Kierdej Jan (Hryćko) z Pomorzan. W: Polski stownik biograficzny. T. 12. Wrocław $1966-1967$.

KIRYK F.: Mężyk Jan z Dąbrowy. W: Polski słownik biograficzny. T. 20. Wrocław 1975. 
Kiryk F.: Sienieński Andrzej z Sienna i Rymanowa. W: Polski słownik biograficzny. T. 37. Warszawa-Kraków 1996-1997.

Kiryk F.: Sienieński Jan z Sienna i Gołogór h. Dębno. W: Polski stownik biograficzny. T. 37. Warszawa-Kraków 1996-1997.

Kiryк F.: Sienieński Wiktoryn z Sienna i Gołogór h. Dębno. W: Polski stownik biograficzny. T. 37. Warszawa-Kraków 1996-1997.

Koczwara M.: Rozwój polodowcowej flory i klimatu Podola w świetle analizy pyłkowej. Lwów 1927 (Prace Geograficzne Wydawane przez Prof. E. Romera, z. 9: Podole).

Korzon T.: Dzieje wojen i wojskowości w Polsce. T. 1. Wyd. II. Lwów-Warszawa-Kraków 1923.

Kowalski M.: Księstwa Rzeczypospolitej. Państwo magnackie jako region polityczny. Warszawa 2013.

Kraków, Archiwum Narodowe, Inwentarz zespotu (zbioru) akt Archiwum Dóbr Pomorzany z lat 1401-1900. Oprac. W. Bukowski. Kraków 1983 (mps).

KurtyKa J.: Odrodzone Królestwo. Monarchia Władysława Łokietka i Kazimierza Wielkiego w świetle nowszych badań. Kraków 2001.

Kurtyka J.: Podole w średniowieczu i okresie nowożytnym. Obrotowe przedmurze na pograniczu cywilizacji. W: J. Kurtyka: Podole w czasach jagiellońskich. Studia i materiały. Oprac. M. WilamowsKi. Kraków 2011.

Kurtyka J.: Wstęp. W: Urzędnicy podolscy XIV-XVIII wieku. Spisy. Oprac. E. Janas, W. Klaczewski, J. Kurtyka, A. Sochacka. Kórnik 1998.

LaberscheK J.: Poczatki i rozwój miasta Szczekociny do końca XV w. Uwagi do genealogii Szczekockich herbu Odroważ. W: Patientia et Tempus. Księga jubileuszowa dedykowana Doktorowi Marianowi Korneckiemu. Kraków 1999.

MALECZYŃsKi K.: Urzędnicy grodzcy i ziemscy lwowscy w latach 1352-1783. Lwów 1938.

MоŻEјко B.: Ród Świnków na pograniczu polsko-krzyżackim w średniowieczu. Gdańsk 1998.

NIEMCZYк K.: Mołdawia w polityce dwóch Jagiellonów: króla polskiego Jana Olbrachta i króla Węgier Władystawa (do roku 1501). W: Wielowiekowe bogactwo polsko-rumuńskich związów historycznych i kulturowych. Suceava 2014.

PAJEwSKI J.: Szlachcic polski dyplomata tureckim (Jan Kierdej Said-bej). „Miesięcznik Heraldyczny" 1935, T. 14.

PAPÉE F.: Jan Olbracht. Kraków 1936.

PlewCZyŃski M.: Wojny Jagiellonów z wschodnimi i potudniowymi sąsiadami Królestwa Polskiego w XV wieku. Siedlce 2005.

PoL W.: Rzut oka na pótnocne stoki Karpat i przyległe im krainy. Kraków 1851.

Prochaska A.: Podole lennem Korony 1352-1430. „Rozprawy Akademii Umiejętności, Wydział Historyczno-Filozoficzny" 1895, Seria 2, T. 7 (32).

Prochaska A.: Poturczeniec dyplomata. „Przewodnik Naukowy i Literacki” 1920, T. 48, z. 6.

Przyboś K.: Wielka własność ziemska w powiecie lwowskim $w$ drugiej polowie XVII wieku. W: Język, literatura, kultura, historia Ukrainy. Materiaty z międzynarodowej konferencji naukowej poświęconej dziesięcioleciu krakowskiej ukrainistyki uniwersyteckiej. Red. W. Mokry. Kraków 2003.

PUŁaski K.: Ród Kierdejów podolskich, monografia historyczno-genealogiczna. W: K. PUŁASKI: Szkice i poszukiwania historyczne. Seria 3. Kraków 1906.

RACIBORSKI M.: Mapa geobotaniczna ziem polskich i jej objaśnienie. W: Encyklopedia polska. T. 1. Dział I, II: Geografia fizyczna ziem polskich i charakterystyka fizyczna ludności. Kraków 1912.

SiKora F.: Kilka uwag o konflikcie zbrojnym wegiersko-polskim w 1410 r. „Rocznik Naukowo-Dydaktyczny WSP w Krakowie. Prace Historyczne" 1987, z. 109. 
Sikora F.: Sieniawski Gunter. W: Polski stownik biograficzny. T. 37. Warszawa-Kraków 1996-1997.

SiKoRA F.: Starostwo szydłowskie z jurysdykcja grodzka w latach 1394-1438. „Archaeologia Historica Polona" 2005, T. 15, z. 2.

SiKora F.: Wielkorzady krakowskie na przełomie XIV i XV wieku. W: Urzędy dworu monarszego dawnej Rzeczpospolitej i państw ościennych. Red. A. GĄSIOrowski, R. SKowron. Kraków 1996.

Słownik geograficzny Królestwa Polskiego i innych krajów słowiańskich. Red. F. SulimiersKI, B. Chlebowski, W. Walewski. T. 1-15. Warszawa 1880-1914.

Stownik staropolski. T. 10, z. 3. Wrocław 1990.

SMOLEŃSKI J.: O powstaniu pótnocnej krawędzi podolskiej i o roli morfologicznej młodszych ruchów Podola. Kraków 1910.

SPerka J.: Otoczenie Władysława Opolczyka w latach 1370-1401. Studium o elicie władzy $w$ relacjach z monarcha. Katowice 2006.

SPERKa J.: Władysław książę opolski, wieluński, kujawski, dobrzyński, pan Rusi, palatyn Wẹgier i namiestnik polski (1326/1330 - 8 lub 18 maja 1401). Kraków 2012.

Spieralski Z.: Po klęsce bukowińskiej 1497 roku. Pierwsze najazdy Turków na Polskę. „Studia i Materiały do Historii Wojskowości” 1963, T. 9, Cz. 1.

SRoKowsKi S.: Zarys geografii fizycznej ziem polsko-litewsko-ruskich. Kijów 1918.

Szaraniewicz I.: Rys wewnętrznych stosunków Galicyi Wschodniej w drugiej połowie XV wieku. Lwów 1969.

SzyBKowski S.: Migracje zamożnej szlachty i możnowładztwa z Kujaw i ziemi dobrzyńskiej na koronna Ruś w XV w. W: Via viatores quaerit. Mobilność spoleczna w dziejach krajów Grupy Wyszehradzkiej. Red. A. Teterycz-Puzio, L. Kościelak, E. ŁąCZyŃsKa. Słupsk 2016.

SZYSZKA J.: Formowanie i organizacja dóbr monarszych w ziemi lwowskiej od połowy XIV do poczatku XVI wieku. Kraków 2016.

SzyszKa J.: Ksztaltowanie się podziałów terytorialnych Rusi Czerwonej na przyktadzie ziemi lwowskiej. W: „Średniowiecze Polskie i Powszechne”. T. 3 (7). Red. J. SPerka, B. CzwoJDRAK. Katowice 2011.

Szyszka J.: Świnka Jan z Pomorzan (Pomorzański) h. Kierdeja. W: Polski stownik biograficzny. T. 51. Warszawa-Kraków 2016-2017.

TęGowski J.: Pierwsze pokolenia Giedyminowiczów. Poznań-Wrocław 1999.

Usma M.: Latyfundium Jana Sobieskiego 1652-1696. Opole 2005.

Urzędnicy betscy i chetmscy XIV-XVIII wieku. Spisy. Oprac. H. Gmiterek, R. Szczygiet. Kórnik 1992 (Urzędnicy dawnej Rzeczypospolitej XII—XVIII wieku. Spisy. Red. A. GĄSIOROWSKI. T. 3, z. 2: Ziemie ruskie).

Urzędnicy małopolscy XII-XV wieku. Spisy. Oprac. J. Kurtyka, T. Nowakowski, F. Sikora, A. Sochacka, P.K. Wojciechowski, B. Wyrozumska. Kórnik 1990 (Urzędnicy dawnej Rzeczypospolitej XII-XVIII wieku. Spisy. Red. A. Gąsıorowski. T. 4, z. 1: Małopolska).

Urzędnicy podolscy XIV—XVIII wieku. Spisy. Oprac. E. Janas, W. Keaczewski, J. Kurtyka, A. SochacKa. Kórnik 1998 (Urzędnicy dawnej Rzeczypospolitej XII-XVIII wieku. Spisy. Red. A. Gąsionowski. T. 3, z. 2: Ziemie ruskie).

Urzędnicy województwa ruskiego XIV—XVIII wieku (ziemie halicka, lwowska, przemyska, sanocka). Spisy. Oprac. K. Przyboś. Wrocław 1987 (Urzędnicy dawnej Rzeczypospolitej XII-XVIII wieku. Spisy. Red. A. GąsIorowski. T. 3, z. 1: Ziemie ruskie).

Wdowiszewski Z.: Genealogia Jagiellonów i domu Wazów w Polsce. Kraków 2005.

Wilamowski M.: Jakub Strepa. W: Polski słownik biograficzny. T. 44. Kraków 2006-2007. 
Wroniszewski J.: Król jako właściciel ziemski w średniowiecznej Polsce. W: Król w Polsce XIV i XV wieku. Red. A. Marzec, M. Wilamowski. Kraków 2006.

Wroniszewski J.: Szlachta ziemi sandomierskiej w średniowieczu. Zagadnienia społeczne i gospodarcze. Poznań-Wrocław 2001.

ZAMORSKi B.: Kronika Pomorzańska wedtug źródeł miejscowych opowiedziana. Lwów 1867.

ZielińsCy G. i J.: Wiadomość historyczna o rodzie Świnków oraz rodowód pochodzacych od nich rodziny Zielińskich herbu Świnka. Cz. 1. Toruń 1880.

Janusz Szyszka

\section{Pomorzany grounds of the Kyerdeys (Kyerdeyevitches)} in the fifteenth-century Lvov area

Summary

The article discusses the history of the Pomorzany grounds, which were situated in the Lvov area, till the end of the fifteenth century. The set of grounds was situated in the basin of the Złota Lipa River around the town and castle of Pomorzany. The extant sources allow us to trace and analyze the process of creation of this set of grounds. It appears that in the earliest preserved documents it is recorded that the grounds, situated in the valley of one river and its tributaries, formed a common settler ecumen. Its creation was determined by the ground formation of this part of the Podole plateau. The marshy and wide river valleys and their mild slopes were a more propitious place for the development of settlements than the steep ridges that were thickly covered with woods. The upper parts of the plateau remained outside the settlement sphere. The Pomorzany grounds were owned by the wealthy boyar family of Kyerdeys, who originated from Volyn and Podole. Its four lines (the Świnkas, the Kyerdey from Pomorzany who were descendants of Jan Hryćko, the Szpikłoskis, and the Urmańskis) related themselves to this possession for good till the extinction of the first two lines in dramatic circumstances at the turn of the sixteenth century. Efficiently administering the grounds, the Kyerdeys transformed them in the fifteenth century into a modern and well-developed set of possessions. Owing to internal colonization they densified the settlement and started to fully use the land economically within these grounds; the land had so far been inaccessible. They started to administer the woods that were growing on the upper parts of the ridges, dried a part of the bog, and banked up the rivers and the brooks, thus creating chains of ponds. They increased the area of the Pomorzany grounds by taking over and settling the settlements that so far had been situated on the outside. This example illustrates the process of linearizing borders of properties by taking over deserted settlements and gradual narrowing down and then abolishment of borders between properties. All of the above was characteristic of the Red Rus in the historical period in question. The settlement structure, which was started at the time and developed in the centuries to come, influenced the organization of geographic space and landscape till the industrial times. The traces of this structure have been preserved up till now.

Key words: Pomorzany, the Kyerdey family, property, landscape, borders, settlement, Red Rus 
Janusz Szyszka

\section{Pomorjanische Güter von Kierdej (Kierdejowicz) im Lemberger Land im fünfzehnten Jahrhundert}

\section{Zusammenfassung}

Der Artikel widmet sich der Geschichte von Pomorjanischen Gütern im Lemberger Land bis Ende des fünfzehnten Jahrhunderts. Dieses Gebiet lag am Fluss Solota Lypa rund um die Stadt und das Schloss Pomorjany. Dank den erhaltenen Quellen kann die Entstehungsgeschichte der Güter verfolgt und analysiert werden. Es ergibt sich daraus, dass die im Tal eines Flusses und ihrer Nebenflüsse gelegenen Güter bereits in dem frühesten nachweisbaren Zeitraum eine gemeinsame Ökumene bildeten, was u.a. durch die Landschaft dieses Teils der Podolischen Platte bedingt war. Sumpfige und breite Flusstäler mit hügeligen Ufern boten siedlungsgünstigere Bedingungen als steile, dicht bewaldete Berge. Die oben gelegenen Gebiete der Platte blieben zunächst unbesiedelt. Die Besitzer von Pomorjanischen Gütern war die wohlhabende Bojarenfamilie Kierdej, die aus Wolhynien und Podolien stammte. Ihre vier Linien (Świnka, Kierdej aus Pomorjany - Nachkommen von Jan Hryćko, Szpikłoski und Urmański) waren lange Zeit mit dem Gut verbunden, bis die zwei ersten Erblinien Ende des fünfzehnten bzw. Anfang des sechzehnten Jahrhunderts unter dramatischen Umständen erloschen. Durch geschicktes Wirtschaften verwandelten die Kierdejs ihre Güter im fünfzehnten Jahrhundert in ein modernes und prosperierendes Landgut. Dank der inneren Kolonisation erhöhten sie die Bevölkerungsdichte und begannen, die bisher unerreichbaren Flächen im Inneren ihres Landes durch Bewirtschaften von Wäldern in oberen Teilen der Berge, Trockenlegung von Sümpfen, sowie Stauung von Flüssen und Bächen zu einer Teichkette voll wirtschaftlich zu nutzen. Darüber hinaus vergrößerten sie die Pomorjanischen Güter durch Übernahme und Besiedlung der anliegenden siedlungsleeren Gebiete. Dieses Beispiel veranschaulicht sehr gut den für Rotrussland jener Zeit charakteristischen Prozess der Linearisierung von Landesgrenzen durch Besetzung der Siedlungsleeren zwecks allmählicher Verengung und im Resultat Abschaffung der Grenzgebiete zwischen den Landgütern. Die zu diesem Zeitpunkt entstandene und in den folgenden Jahrhunderten entwickelte Siedlungsstruktur hatte einen Einfluss auf die Entwicklung der Raum- und Landschaftsplanung bis ins Zeitalter der Industrialisierung und deren Spuren blieben bis zum heutigen Tag erhalten.

Schlüsselwörter: Pomorjany, Familie Kierdej, Landgut, Landschaft, Grenzen, Besiedlung, Rotrussland 